\title{
WORLD
}

RESOURCES

WORKING PAPER

\author{
I N S T I T UT E
}

\section{A GUIDE TO ASSESSING THE POLITICAL ECONOMY OF DOMESTIC CLIMATE CHANGE GOVERNANCE}

\section{JESSE WORKER AND NIKI PALMER}

\section{EXECUTIVE SUMMARY}

\section{Highlights}

- There is overwhelming evidence of the social, economic, and environmental case to reduce greenhouse gas (GHG) emissions and rapidly scale up adaptation. Yet, despite a proliferation of climate laws and policies over the last 10-15 years, emissions are still rising, and adaptation needs remain urgent.

This calls for a more sophisticated assessment of the political economy factors that may enable or constrain implementation of policies and actions and sustain political commitment at the country level.

- This guide offers an assessment methodology to understand how structural factors, rules and norms, stakeholders and interests, and ideas and narratives influence the political economy of climate action in a given country context.

The methodology was developed on the basis of climate policy, governance, and political economy literature with contributions from subject matter experts.

We intend the assessment to support civil society coalitions, reform-minded civil servants and politicians, international organizations, and other stakeholders.

The resulting analysis should deepen the understanding of context while informing the advocacy, policy design, coalition building, capacity building, and communications of domestic stakeholders.

\section{CONTENTS}

Executive Summary ...................................1

1. Introduction 2

2. Why Governance and Political Economy

Matter for Climate Action 3

3. Climate Change Presents Unique

Governance Challenges

4. How Political Economy Analysis Has

Encouraged Appreciation of "Politics Matter"......... 9

5. Conducting a Political Economy Analysis .......... 10

6. Making Sense of the Results..................... 19

7. Conclusion ...........................................20

Appendices..................................... 21

Endnotes ......................................... 32

References .......................................... 33

Acknowledgments..................................36

About the Authors .................................... 36

Working Papers contain preliminary research, analysis, findings, and recommendations. They are circulated to stimulate timely discussion and critical feedback, and to influence ongoing debate on emerging issues. Working papers may eventually be published in another form and their content may be revised.

Suggested Citation: Worker, J., and N. Palmer. 2020. “A Guide to Assessing the Political Economy of Domestic Climate Change Governance." Working Paper. Washington, DC: World Resources Institute. Available online at doi.org/10.46830/wriwp.18.00047. 


\section{The Political Economy of Climate Change Governance}

Despite overwhelming evidence that the social, economic, and environmental benefits of ambitious climate action outweigh the costs, only a handful of countries have made policy commitments in line with the temperature goals of the Paris Agreement. Given that none of these countries classifies as high-income, it is apparent that capacity, access to technology, and policy expertise alone are not sufficient to ensure political ambition. A lack of "political will," due in large part to the influence of vested interests, is often cited as a major culprit, but we do not think this superficial analysis helps stakeholders develop political strategies to ratchet up ambition or strengthen the enabling environment for implementation. A more systematic assessment of the political and institutional context, as well as the dominant ideologies and narratives, can help stakeholders take additional steps to build political support or strengthen rules and capacities guiding implementation.

While there is growing political economy literature on climate change-particularly on energy transitions-we have yet to see a guide designed to help multisector national coalitions that are grappling with diverse climate governance challenges. Such challenges include improving coordination across sectors and scales, building the capacity and incentive structure for accountability systems to work, and enabling more transparent monitoring of progress of policy implementation, to name a few. We argue that any assessment of climate governance-rules, structures, and capacities that shape interaction between actors-must consider the political and economic interests, incentives, and relationships that motivate actions. Given the urgency of shifting emissions trajectories in the short term to reach long-term goals, climate advocates must build political power quickly.

\section{About This Working Paper}

This working paper draws from the literature on climate governance and political economy (PE) more broadly to develop a guide for assessing how structural factors, rules and norms, stakeholder relationships, incentives and interests of key actors, and ideas and narratives shape power and influence in domestic climate governance. It is primarily intended to help domestic coalitions of civil society actors as well as policymakers and civil servants who are grappling with, or anticipate challenges of political commitment, coordination, and accountability. We hope that this working paper will help these actors be better positioned to anticipate the political response of proposed climate policies and identify actions that will grow constituencies, shift incentives for behavior change, and amplify the contributions of non-state actors. This guide will be piloted in 2020 and 2021 with the aim of using feedback to finalize the framework.

\section{Political Economy Assessment for Domestic Climate Governance}

This guide has been developed on the basis of assessment questions categorized under structural factors, rules and norms, stakeholders and interests, and ideas and narratives. The assessment is problem-driven, meaning that it is designed for stakeholders to apply to a specific problem (e.g., harnessing political support for mitigation or adaptation ambition) that they have identified, rather than to provide a broad overview of domestic climate governance. We made this choice so that the results are more specific and actionable. The guide is customizable, in that users can focus on questions that are most relevant to their problem. It is also intended to be iterative so that stakeholders can monitor for changing political economic conditions. Because it is meant to be useful to advocates working on a range of climate governance challenges, it does not go into technical depth on any particular policy area. Nor is it a policy assessment tool, but rather a governance and $\mathrm{PE}$ assessment. It complements existing tools that help stakeholders and decision-makers assess policy options, ${ }^{1}$ address gender equality, ${ }^{2}$ establish legal frameworks, ${ }^{3}$ and support stakeholder engagement by helping to determine the incentives, power structures, and other PE factors that affect the enabling environment for climate action.

\section{INTRODUCTION}

Climate change poses an unprecedented threat to societies around the world. According to an estimate by the United Nations, current policies would lead to a temperature increase of $3.4^{\circ} \mathrm{C}-3.7^{\circ} \mathrm{C}$ by 2100 (United Nations Environment Programme 2019), driven largely by fossil fuel consumption patterns in wealthier and rapidly developing economies as well as deforestation and land-use change. There is now overwhelming evidence that ambitious climate action is essential to reduce poverty and inequality and protect critical ecosystems that underpin economic prosperity. Yet, political commitment and governance in many countries has failed to deliver investment, regulation, and behavioral change for what's 
required. This is reflected in both stated commitments and the lag between commitments and action (NewClimate Institute and Climate Analytics 2019a).

Those countries that have demonstrated commitment in line with the Paris Agreement's goals tend to be less wealthy, more vulnerable to the impacts of climate change, and lower GHG emitters. As of mid-2020, 104 countries had stated their intention to enhance ambition, but their combined emissions account for only 27.1 percent of global emissions (Climate Watch 2020). ${ }^{4}$ Additionally, of the 32 countries $^{5}$ whose climate ambition is tracked by the Climate Action Tracker, only 8 rated as compatible with the $1.5^{\circ} \mathrm{C}$ goal or the $2^{\circ} \mathrm{C}$ goal-Morocco, The Gambia, Bhutan, Costa Rica, Ethiopia, India, Kenya, and the Philippines. Of these, only India is in the top 10 of carbon emitters (NewClimate Institute and Climate Analytics 2020). Even when laws and policies have been enacted, effective implementation is far from assured. In its landmark Environmental Rule of Law report, the United Nations found that effective implementation of environmental laws is often hindered by insufficient civic engagement, lack of respect for human rights, and institutions lacking capacity, accountability, resources, integrity, and leadership (Bruch et al. 2019).

The Intergovernmental Panel on Climate Change (IPCC), citing Jagers and Stripple (2003), refers to climate governance as the "mechanisms and measures 'aimed at steering social systems towards preventing, mitigating, or adapting to the risks posed by climate change."'6 It also notes that "it goes beyond notions of formal government or political authority and integrates other actors, networks, informal institutions, and incentive structures operating at various levels of social organization" (Edenhofer et al. 2014). Political economy analysis examines the competing factors that drive or block changes in a country's policies or practices, from human agency (the interests, incentives, or ideas of individual or organizations) to institutional or structural factors (North 1990). Climate action in all countries, regardless of development status, is subject to competing domestic and international political priorities, shifting public sentiment, and special interest lobbying.

The objectives of this working paper are two: to

provide guidance, drawing from the climate governance and PE literature and country examples, on how $\mathrm{PE}$ and governance interact at the country level; and provide domestic stakeholders with an assessment framework and questions to unpack the PE dimensions of a climate governance challenge in their country.

Ultimately, we hope this will help users develop political strategies for policy enactment, target capacity building and incentives, and identify mechanisms to strengthen the domestic enabling environment for increasing climate ambition.

\section{WHY GOVERNANCE AND POLITICAL ECONOMY MATTER FOR CLIMATE ACTION}

Governance and PE are critical determinants for sustainable development, equity, and climate change mitigation because they circumscribe the process through which these goals and how to attain them are articulated and contested (Edenhofer et al. 2014, 297). On the face of it, there are many compelling reasons for governments to invest in climate action. The Global Commission on Adaptation found that US $\$ 1.8$ trillion invested in the next five years could produce $\$ 7.1$ trillion in benefits by 2030 (Global Commission on Adaptation 2019). Modeling conducted by the New Climate Economy found that ambitious climate action could lead to 37 million net new jobs globally and avoid 700,000 premature deaths from reduced air pollution by 2030 (Global Commission on the Economy and Climate 2018). Yet, obstacles to domestic progress on climate goals persist in most countries. Capacity building, domestic and international finance, and transfer of technology are all critical components of effective climate responses, but it is evident that even wealthy and high-capacity countries face major political obstacles to enacting and effectively implementing climate policies. ${ }^{7}$ None of the countries rated by the Climate Action Tracker ${ }^{8}$ as having policies in place to meet the temperature goals of the Paris Agreement are classified as high-income by the World Bank. ${ }^{9}$ An estimated $\$ 296$ billion ${ }^{10}$ in fossil fuel subsidies globally in 2017 (Coady et al. 2019) is another example that national governments in many countries have yet to muster the political support to shift incentives and strengthen regulations to ensure that policies and actions are aligned with rhetoric.

This working paper recognizes that capacity is an important component of transformative change but argues that PE factors shape domestic climate governance and can reveal a much more nuanced picture of why obstacles, including limited capacity, persist. 
For instance, longstanding promotion of fossil fuel subsidies can be extremely difficult to change because of the vested interests keeping them in place. Similarly, fuel supply monopolies, biased energy distribution, and rent-seeking arrangements that contribute to party finances can all influence the likelihood of reforms taking place, and often limit climate action. PE factors exacerbate climate governance issues that commonly include inad- equate legislation, weak capacity, and inefficient coordination across stakeholders.

The available literature provides several examples of PE challenges to a range of climate policy issues, including fossil fuel subsidy reform, carbon pricing, and adaptation options to address climate risk. Table 1 provides a brief summary.

\begin{tabular}{|c|c|c|c|}
\hline POLICY AREA & POLICY BENEFITS & POTENTIAL POLITICAL ECONOMY FACTORS & POTENTIAL REMEDIES \\
\hline $\begin{array}{l}\text { Fossil fuel subsidy } \\
\text { removal }\end{array}$ & $\begin{array}{l}\text { - Reduced emissions } \\
\text { - Increased government } \\
\text { revenue and/or reduced } \\
\text { expenditures } \\
\text { - More efficient allocation of } \\
\text { resources } \\
\text { - Public health and } \\
\text { environmental benefits }\end{array}$ & $\begin{array}{l}\text { Concentrated costs on high-emitting industries, } \\
\text { dispersed public benefits } \\
\text { - Customers expect low fuel bills; government } \\
\text { may fear losing votes and campaign financing if } \\
\text { subsidies are reformed } \\
\text { - Dominant narratives on subsidies, economic } \\
\text { development, and poverty alleviation } \\
\text { - Extensive rent-seeking connected to fuel } \\
\text { subsidies can disincentivize reform; rent-seeking } \\
\text { may implicate powerful actors }\end{array}$ & $\begin{array}{l}\text { - Visible investments in social safety } \\
\text { net and public programs to offset } \\
\text { concern of affected voters } \\
\text { - Reductions in other regressive } \\
\text { taxes, such as sales tax } \\
\text { - Use increased revenue to fund } \\
\text { direct cash transfers } \\
\text { - Communication campaigns }\end{array}$ \\
\hline Carbon pricing & $\begin{array}{l}\text { - All of the above, plus: } \\
\text { - Internalizes costs of fossil } \\
\text { fuels to reduce demand } \\
\text { - Provides incentives for } \\
\text { deployment of clean } \\
\text { technologies } \\
\text { - Raises revenue that can be } \\
\text { distributed or invested in } \\
\text { ways that generate public } \\
\text { support and address equity } \\
\text { and just-transition issues }\end{array}$ & $\begin{array}{l}\text { - Distributional impacts of higher fuel prices on } \\
\text { - Voorer populations } \\
\text { - Visible cost increases provide support to } \\
\text { organized opposition } \\
\text { - Social and political context-wealth inequality, } \\
\text { stagnant wages, weakening social safety net- } \\
\text { may adversely impact implementation }\end{array}$ & $\begin{array}{l}\text { - All of the above, plus: } \\
\text { - Thorough distributional and social } \\
\text { impact assessment } \\
\text { - Redistributive approach to revenue } \\
\text { allocation } \\
\text { - Stakeholder-driven process to } \\
\text { build understanding of revenue } \\
\text { allocation options and enable } \\
\text { public input } \\
\text { - Phase in of carbon price } \\
\text { complemented by sector policies } \\
\text { - Highly visible investments with } \\
\text { revenue to build constituencies }\end{array}$ \\
\hline $\begin{array}{l}\text { Adaptation to } \\
\text { extreme weather } \\
\text { events and slow- } \\
\text { onset changes }\end{array}$ & $\begin{array}{l}\text { Infrastructure that is less } \\
\text { exposed and less sensitive } \\
\text { to extreme weather } \\
\text { - Greater access to climate } \\
\text { finance and adaptation } \\
\text { decision-making for } \\
\text { affected groups } \\
\text { - Livelihood opportunities } \\
\text { that are compatible with a } \\
\text { changing climate }\end{array}$ & $\begin{array}{l}\text { - Pressure to continue practices (infrastructure, } \\
\text { agriculture, etc.) that provide short-term political } \\
\text { and economic benefits at the expense of } \\
\text { medium- to long-term resilience } \\
\text { - Potential privatization of public lands or } \\
\text { resources } \\
\text { - Prioritization of geographical areas } \\
\text { concentrating population and economic interests } \\
\text { - Adaptation policies that address marginalization } \\
\text { may directly challenge social norms or power } \\
\text { - } \text { structures } \\
\text { - Eevolution of power from central actors } \\
\text { - Exacerbating wealth or gender inequalities }\end{array}$ & $\begin{array}{l}\text { - Justice and equity requirements in } \\
\text { decision-making } \\
\text { - Representation of marginalized } \\
\text { groups in decision-making } \\
\text { committees } \\
\text { - Procedural safeguards for } \\
\text { grievance and redress } \\
\text { - Strong oversight of the } \\
\text { enforcement of zoning and land- } \\
\text { use regulations }\end{array}$ \\
\hline
\end{tabular}


Because climate change cuts across a range of sectors and interests, it has the potential to attract interest from a wide range of stakeholders. However, every country has its own power hierarchy that determines the effectiveness of interested stakeholders in influencing climate policies. Some countries operate under a highly centralized government, with power tightly controlled and limited devolution to local levels, while others experience varying degrees of decentralization. Competitive political systems hold elections and may develop a vibrant civil society, although both elections and civil society may still be constrained. Noncompetitive, "dominant," and/or authoritarian systems reflect the personality of the state's leader and may be less subject to the rule of law, with implications for the transparency of institutions and the ways in which data are used (Levy 2014). In many parts of the world, formal and informal (customary) forms of governance overlap, reinforce one another, and sometimes come into conflict (World Bank Group 2017). Customary governance structures are often based on and reinforce ethnic, religious, clan-based, or tribal interests and allegiances and can include chiefdoms, religious organizations, and local village councils. ${ }^{11}$

While the scope of this working paper is domestic climate governance, international networks can play an important role in influencing governance forms and capacities at the country level. These networks may comprise diverse stakeholders and highlight the role of nonnational actors, such as cities, subnational governments, businesses, and civil society organizations that are making commitments, developing standards, and developing shared capacity through learning and access to finance that either amplify their national governments' actions or fill the space where national actors are contributing little. ${ }^{12}$

There is growing scholarship on polycentricity in climate governance-as opposed to monocentricity (i.e., national government as the sole decision-maker)-where actors and organizations at different levels operate with varying degrees of, at times, overlapping authority and interact with each other to share information and resources (Jordan et al. 2018; Morrison et al. 2017). These systems are often characterized by policy experimentation, networks, and decentralization. In practical policy terms, this may include cities sharing information and resources to develop their 2050 net-zero commitments, donors working with South African communities to establish direct financing for local adaptation priorities, or the decentralized and at times overlapping authorities at the federal, state, and local level that govern coastal adaptation in California (Adaptation Fund 2020; C40 Cities 2020). While we have not framed this assessment as a tool to better understand polycentric governance, the assessment questions described in Section 5.3 below (and presented in full in Appendices A to D) may be helpful in considering the structures, relationships, and power dynamics between actors and stakeholders at different scales (Morrison et al. 2017).

\section{CLIMATE CHANGE PRESENTS UNIQUE GOVERNANCE CHALLENGES}

Disrupting carbon lock-in is fundamentally a political activity because lock-in has significant political foundations: it rests on norms, institutions, capacities, and coalitions that support fossil energy dependent systems (Bernstein and Hoffman 2018).

Since climate is a global public good, reducing emissions to reach a global goal presents the most consequential collective action problem humanity has faced. Countries cannot be sure that the political and economic capital they expend on climate solutions will be matched by others. The long-term economic, social, and environmental benefits of reducing emissions won't be felt by today's electorate, dampening direct political incentives. Those stakeholders who have directly benefitted from systems, practices, and policies that have caused climate change often have longstanding political economic influence that can stymie or delay changes. This is the overarching and generally well-understood PE context of climate governance. However, it is critical to understand a country's institutions, actors, and interest groups to understand how policy breakthroughs occur (Mildenberger 2020) and understand how to encourage enabling conditions for more ambitious action.

\subsection{International Context of Domestic Governance}

The 2015 Paris Agreement establishes a global goal of limiting warming to well below $2^{\circ} \mathrm{C}$ above preindustrial levels, with efforts to limit it to $1.5^{\circ} \mathrm{C}$. The Paris Agreement also aims to enhance adaptive capacity, strengthen resilience, and ensure financial flows consistent with low-carbon, climate-resilient development. While the agreement does not legally bind any one party to specific emissions reductions, it establishes a set of procedural obligations designed to generate trust and facilitate more ambitious action over time (Van Asselt and Zelli 2018; 
Dagnet et al. 2019). Parties have new or enhanced obligations to communicate their actions through Nationally Determined Contributions (NDCs), report their progress and the support ${ }^{13}$ provided or received with greater clarity, and participate in periodic reviews, such as the review and compliance mechanism and the five-year "global stocktake," to assess collective progress (Elliot et al. 2017).

These obligations create new responsibilities that require capacity building (Dagnet et al. 2019) and introduce new incentives (through finance, capacity building, and reporting requirements) for elected officials and civil servants. Seventy-eight percent of NDCs contain two sets of commitments: those that will be undertaken with domestic resources and more ambitious commitments that are conditional on some form of international finance or support (Taibi and Konrad 2016). Thus, the political economies of climate action are linked across countries-failure of wealthier countries to generate sustained commitment to meet international finance goals may undermine the capacity and ambition in developing countries around the world. For instance, the Yasuni-ITT Initiative in Ecuador would have left nearly one billion barrels of crude oil "locked in perpetuity" underneath a highly biodiverse nature reserve and indigenous territory in exchange for $\$ 3.6$ billion, but the international community mobilized only $\$ 13$ million (0.5 percent of the total). While there was also domestic pressure to exploit the oil, this failure is considered a major reason why former Ecuadorian president Rafael Correa canceled the initiative in 2013 (Sovacool and Scarpaci 2016).

The Paris Agreement does not extend obligations on domestic governance arrangements; ${ }^{14}$ for instance, how information related to implementation of national climate policies should be made available to the public. Given the bottom-up nature of the agreement, countries will make their own determinations on how to develop institutional capacity, assign rights and responsibilities, and hold public and private actors accountable.

\subsection{Uncertainty, Non-linearity, and Irreversibility}

Uncertainty regarding future emissions pathways, non-linearity in climatic and ecosystem responses, and the socioeconomic impacts of national-level measures developed on the basis of downscaled global-level climate models are real challenges. However, they must not prevent policymakers and planners from taking action (Allen et al. 2019). While many forms of policymaking and implementation are time-sensitive, climate governance is especially so; delayed implementation represents a far greater risk to future generations.

There is growing scientific evidence that continued warming could cross biophysical thresholds, causing cascading and catastrophic impacts such as destabilization of ice sheets and glaciers, ecosystem collapse, disruption of oceanic and atmospheric currents, and extreme heat, storms, and drought that exceed the capacity of societies to adapt. Many of these system changes may be irreversible on a human timescale (DeFries et al. 2019). Yet, there is evidence that economic assessments of climate risks have neglected to convey the scale and magnitude of these risks to political leaders and public authorities (DeFries et al. 2019).

\subsection{Procedural and Distributive Equity}

Some countries are committed to taking action to reduce emissions and build resilience but should be aware of the risk that climate decision-making processes and resulting actions can perpetuate or even worsen social inequities. Such unintended consequences can result from both decision-making processes and the distribution of policy benefits and costs. Climate actions can worsen the lot of population groups historically subject to social discrimination or legal, political, and economic disenfranchisement. These groups tend to be less well connected to public services, more exposed to climate risk, employed in occupations that are threatened due to shifts in response to climate change, or have low levels of trust in or access to public authorities (Roy et al. 2018). 
Given these sociopolitical factors, the scale of economic transformation required, and the existential threat of climate change, national dialogues on climate action are likely to focus as much on the values, rights, and worldviews that shape a country's vision and policy choices. Countries will need to learn from past experiences to ensure greater representation in decision-making processes, especially for affected groups; legal and institutional mechanisms must be in place to ensure downward accountability. Some countries are experimenting with more deliberative approaches-such as citizen assemblies-to address issues of underrepresentation and knowledge and trust gaps, and provide space for discussing trade-offs (Farand 2020). Tools such as distributional or gender impact analysis can inform policymakers and planners on the potential equity impacts of policies but may not guarantee that the results are effectively used without political oversight or pressure from civil society (Johnson et al. 2020).

\subsection{Unprecedented Coordination across Sectors and Scales}

Climate mitigation and adaptation both require structures, incentives, and mechanisms to ensure coordination and cooperation in policy development and implementation. The IPCC has recognized the importance of multilevel governance to enable systemic transformation, build necessary adaptive capacity, manage trade-offs, and ensure the involvement of businesses, local governments, communities, and civil society (Roy et al. 2018). Setting and meeting national mitigation targets will depend on contributions from all economic sectors. This, in turn, will require information and knowledge exchange. PE issues may arise if sectoral authorities perceive climate actions as threatening to their political power or relationships with influential economic actors.

Subnational and non-state actors can contribute directly to emissions reductions and indirectly by supporting new policies, business models, and capacity building, and by joining national coalitions to increase political support (Hale 2018). The degree to which this occurs depends on which actors are mobilized to push for greater ambition (and their relative influence), which actors have the resources and authority to implement policies, and to what extent non-state and sub-state actions are integrated into national policies (Hale 2018).

\section{Box 1 | Balancing Priorities, Aligning Interests: Framing of Mitigation in China and India}

Harrison and Kostka (2013) focus on the strategies used

by agencies within the governments of China and India to

influence and include climate action in government-wide

agendas. Despite the significant difference between these

two contexts, the authors point to the use of similar tactics

to reconcile climate change mitigation with competing

policy interests. Focusing on energy efficiency to explore

how government agencies seek to overcome challenges of

limited capacities and competing policy priorities, they find

an approach known as framing and bundling to be effective,

including leveraging existing government structure to achieve

policy goals.

Framing is a way of packaging potentially controversial

policies with others to reconcile competing interests and

reduce pushback. Harrison and Kostka refer to the impact

of air pollution in China on the framing of climate change,

which since 2012 has shifted to focus on sustainability and

environmental stewardship. India, using a similar tactic but in

response to a very different set of competing policies, chose a

framing of climate change that is focused on the "challenge of

sustaining its rapid economic growth while dealing with the

global threat of climate change" (Government of India 2008).

Harrison and Kostka demonstrate how these framings, which

are more acceptable to the particular political economies at

play in India and China, provided the basis for bundling.

Bundling strategies in both contexts harnessed the existing institutions and policy mechanisms (policy bundling) to align the interests of different stakeholders with energy efficiency objectives (interest bundling). This example shows clearly that through a more circuitous route, which takes into account the reality of local politics and competing policy priorities, climate mitigation objectives can still be achieved.

Source: Harrison and Kostka 2013. 


\subsection{Durable and Credible Commitments}

Policymakers should consider strategies that minimize the chance of either short-term reversal or longer-term undermining of climate action policies. Opponents who fail to thwart policy enactment may still be able to limit ambition, delay implementation, or overturn a policy in a different institutional venue or following a change in political leadership..$^{15} \mathrm{~A}$ political economy analysis (PEA) can inform policy design to safeguard against reversal and foster deeper and broader support among existing and new constituencies. For instance, policies that set in motion investment decisions, deliver visible short-term material benefits, or create markets for growing industries can raise the political and economic costs of policy reversal while increasing benefits and expanding constituencies over time (Levin et al. 2012).

\section{Box 2 | The United Kingdom's Climate Change Committee}

The UK's 2008 Climate Change Act was the world's first

long-term, legally binding framework law to address

emissions reductions. Over the course of a decade, it has

succeeded in reducing emissions (particularly in the power

sector), withstanding political opposition, and transforming

climate governance in the UK. While the legally binding

long-term emissions reductions are important, arguably it

is the institutions of monitoring, transparency, and public

accountability that have made the act endure thus far.

The Grantham Research Institute on Climate Change and

the Environment at the London School of Economics and

Political Science conducted interviews with 33 high-level UK

policymakers and found that the most important features

of the act have been the long-term emissions target, an

empowered independent advisory body, mandatory five-

year carbon budgets, mandatory government reporting

to Parliament and the public, and an iterative five-year

adaptation planning cycle to ensure learning and flexibility.

The independent oversight function has helped create the

norm of parliamentary and public scrutiny of climate change

progress.

Source: Frankhauser et al. 2018
Safeguarding policies for long-term continuity can help establish a "political logic" for policymakers to ratchet up ambition over time, which may be the only realistic path for countries where high-ambition policies are unable to muster political support at the outset (Levin et al. 2012). Contrasting the early years of feed-in tariff policies in the United Kingdom and Germany, Lockwood (2016) finds that price guarantees, renewable energy supply chains, complementary industrial policy, and other policy features in Germany opened up the renewable market to small-scale local providers. Over time, broad coalitions of interest groups developed that were able to provide political protection. According to the author, the absence of these features in the UK reinforced structural barriers to entry for households and other small-scale producers which could have expanded constituencies for the policy at an earlier stage (Lockwood 2016). Legislation, institutional mechanisms such as multi-stakeholder bodies, and authorization of independent, nonpolitical entities to play key monitoring and oversight roles can all contribute to the long-term policy continuity and credibility of commitments (Averchenkova and Bassi 2016).

In a comparative assessment of how and why different carbon pricing efforts have succeeded or failed politically, Rabe (2018) found that strategic use of revenue allocation to build constituencies, bundling price mechanisms with other more politically popular climate measures, and establishing a governance architecture and staffing plan to guide implementation all played an important role in determining which carbon pricing mechanisms endured and which failed in Canada and the United States. In his global analysis of the political success of carbon mitigation policies, Mildenberger (2020) argues that climate policy advocates have focused too much on reducing economic incentives to pollute and not enough on policies that disrupt entrenched political power. The author notes that carbon pricing brings the issue of costs to the front while obscuring the benefits. The implication is that policies should be evaluated not only on their mitigation potential, but also their political ambition in terms of disrupting entrenched carbon-dependent interests. The political strategy chosen will depend on whether a country's policymaking institutions favor pluralist interest-group politics or more institutionalized bargaining between the state, labor, and business groups in a corporatist system (Mildenberger 2020). 
For parliamentarians and policymakers, it may be worth considering how legislation can establish procedures and institutions that help address issues of equity, justice, and power disparities that may adversely impact implementation. Lazarus (2010) provides examples for the US context in Box 3 below.

\section{Box 3 | Building in Barriers to Appeal for Climate Laws in the United States}

Lazarus (2010) argues that "precommitment strategies" could be embedded within the law itself to prevent lawmakers with short-term interests from undoing legislation meant to benefit future generations. Emphasizing the fragmentation of authorities (e.g., committees and subcommittees within Congress) and a structural bias toward incrementalism, he notes that precommitment strategies are especially relevant to environmental laws that have redistributive impacts. Such institutional design features may be balanced with provisions to allow flexibility to adapt to new information-critical for robust climate policies. The author recommends the following asymmetric mechanisms that would favor those who are seeking to protect and strengthen the law but not repeal it:

- Requiring independent analysis of any amendment designed to weaken the law's goals

- Using revenue (e.g., a carbon price) to help insulate from budgetary appropriations processes

- Insulating appointees to chair climate commissions or head new departments through term length and protections against removal

- Requiring interagency coordination activities to be public record so that citizens may file lawsuits if laws are not enforced

- Creating a new expert governmental entity (similar to UK's Committee on Climate Change) to oversee implementation

- Special participatory rights for historically disempowered groups in implementation processes

- Separating policy goals and implementation strategies between executive and legislative branches to protect against purposeful efforts to derail implementation

- Limiting certain types of judicial review and promoting others

Source: Lazarus 2010, adapted from Worker 2017

\section{HOW POLITICAL ECONOMY ANALYSIS HAS ENCOURAGED APPRECIATION OF "POLITICS MATTER"}

Literature on the PE of development stretches back decades but became more prominently used in international development policy only in the early 2000 s (Fisher and Marquette 2014). Concurrently, interest in $\mathrm{PE}$ issues was also increasing in the energy sector, particularly as a means of understanding "why model reform processes had varying outcomes" (Lee and Usman 2018). The first generation of PEA tended to focus on country-level (macro, structural, and political) drivers of institutional performance and change processes in societies (Department for International Development 2004; Fisher and Marquette 2014, 5-6). The second generation focuses on local, sector-level, and procedural political drivers of behavior (Lee and Usman 2018). Over the last 15 years, a set of ideas referred to as "thinking and working politically" (TWP) has emerged, ${ }^{16}$ with the core idea that "development outcomes cannot be achieved by technical solutions alone. Actors-politicians, bureaucrats, civil society, donors, and so on-need to better understand the local context ('thinking politically') in order to support local actors to bring about sustainable developmental change ('working politically')" (Hudson et al. 2018).

Most of the published PEAs addressing climate policy that we identified were focused on carbon pricing and the electricity sector (Arent et al. 2017) and fossil fuel subsidies (Inchauste et al. 2018; Victor 2009), with relatively less published on transportation, energy efficiency, or adaptation (Tanner and Allouche 2011; Sovacool and Linnér 2016). Fay et al. (2015) suggest different policy design options to compensate for distributional impacts and, in some cases, to dampen organized opposition. The beneficiaries of fossil fuel subsidies, who enjoy increased corporate revenue and reduced risks, are often highly organized politically to protect these advantages. Recent national assessments of climate governance conducted by the Climate Action Tracker reviewed evidence of effective institutional frameworks, policy processes, stakeholder engagement, and political commitment (NewClimate Institute and Climate Analytics 2019b). Less study has been devoted to the extent to which informal bargaining processes, influenced by specific cultural norms or motivated by ideology, are identified as important in driving climate actions. Attention is generally directed to factors like government capacity, regulatory ability, strength of the carbon lobby, and the extent of public knowledge of the climate threat. 
The increased interest in utilizing PEA to adapt programming or reshape strategy has not been followed up with adequate evaluations to provide evidence of impact. Where it does exist, evidence can be anecdotal and limited to "insider stories of donor programs, without sufficient comparative or counterfactual analysis" (McCulloch and Piron 2019, citing Piron et al. 2016; Laws and Marquette 2018). Although robust evidence is thin, the many anecdotal examples can provide some insight. In a recent study, McCulloch and Piron (2019) find examples that

\section{Box 4 | Power Sector Reforms in the Dominican Republic}

The Dominican Republic has experienced challenges in the power sector since the early 2000s. In 2005, the country received support from the World Bank to finance and reform the sector-the first part of a package intended to be implemented in three phases. The government's strategy for reform of the power sector was central to the country's wider development plan, indicating political commitment to reforms. There also appeared to be a sense of urgency to work out durable solutions for the sector. Yet, interventions failed to achieve results, in part because the government's payment of its bills to the utility company and its disbursement of subsidies remained irregular. The tariff regime remained too low to cover utility costs. Regulatory oversight also remained weak with no real ability or desire to take action.

The reform program had been designed with the assumption that large and rapid disbursements of budget support would motivate authorities to implement reforms. This backfired, and examination of PE factors showed that the Dominican Republic had previously had difficulty implementing large lending programs, with frequent dilutions of agreed actions. Moreover, the social contract in place led citizens to expect short-term benefits, including low electricity tariffs. Politicians' incentives to adjust tariffs remained low, given that higher tariffs would be unpopular and likely lead to punishment at the next election. The expectations of constituents ended up having more sway on tariff rates than external funding. Put simply, model reforms, incentivized by large-scale funding, failed because of insufficient attention to the prevailing social contract.

A different approach, prioritizing time for more grassroots consultation to build the necessary political coalitions, was agreed to be more likely to lead to reforms in the future. "reconfirm the fundamental importance of 'thinking politically' through PEAs, but go beyond this to highlight how this can be applied in different ways to help programmes adapt to their contexts." However, to our knowledge, these evaluations have not included applications of PEAs to the climate policy domain.

Understanding the political-economic dynamics of previous policy reform attempts can help reveal stakeholder dynamics, interests, and, potentially, new ways of building political support. The example in Box 4 of power sector reforms in the Dominican Republic illustrates how these dynamics stalled reform despite international finance and high-level political support.

\section{CONDUCTING A POLITICAL ECONOMY ANALYSIS}

We developed this assessment with the understanding that climate advocates in different countries face common governance challenges but that they operate in their own specific contexts and with different capacities. Given the scale of action required to reduce emissions and build resilience and the range of potential challenges, the assessment does not try to cover everything. Rather, it offers an approach that can be contextualized and adapted to suit a multitude of conditions and locations. We anticipate that users will have an idea of the major climate policies or actions that need to be implemented (see Step 1 in Figure 1). Users may also have observed or anticipate a governance challenge that is delaying policymaking or implementation or rendering it ineffective or inequitable (see Step 2 in Figure 1 as well as Table 2 for examples). This also means that users should not feel compelled to respond to every question, but rather determine (likely with the input of partners and stakeholders) which are necessary and useful. Practitioner experience in applying PEA-such as from the UK and U.S. governments ${ }^{17}-$ suggests it is most effective when treated less as a product and more as an approach to working. Practically, this means that it should be adaptable so that users can apply it iteratively without being so resource-intensive that it is prohibitively expensive or time-consuming. Figure 1 illustrates how PEA can become part of a cycle of policy and governance change. 


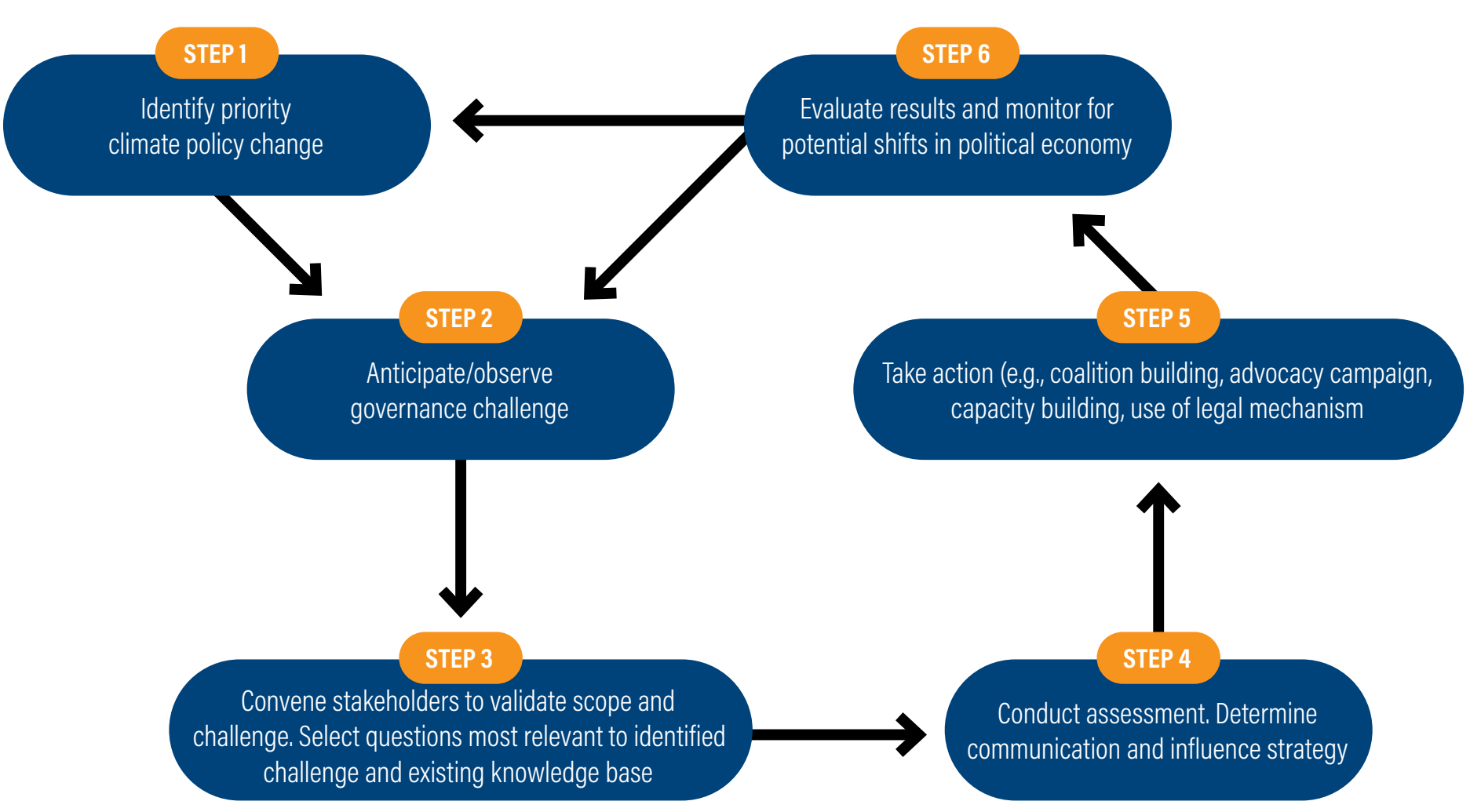

Source: Authors.

The assessment is intended to be used by domestic stakeholders such as civil society coalitions, reformminded civil servants and politicians, but may also be useful to researchers and donor agency staff. However, the audience for an assessment should be further refined to suit context. For instance, an assessment intended to support advocacy regarding specific climate-vulnerable groups or to be used to promote the influence of the private sector. To try and adjust for this, each question has accompanying guidance, potential sources of information, and indications of the type of governance problem that the question is intended to help address. The assessment will be piloted in India and Brazil in 2020-21 to gather feedback that will be used to inform the methodology and assessment questions. The methodology for developing the assessment framework is outlined in Box 5.

\subsection{Getting Started}

From the outset, users of this assessment should consider who their audience will be for the output of the assessment:

Which actors-civil society, legislators, or other elected officials; civil servants, media; or otherwisemay use the results if they have an opportunity to contribute to or are made aware of the work? If there are government officials who may care, are they civil servants, cabinet officials, or parliamentarians? Each category has a different capacity for effecting change.

- Who are the individuals or organizations that should be consulted at the outset of the research to validate the challenge and approach, identify resources, facilitate interviews, and serve as messengers for the results? 


\section{Box 5 | Methodological Approach}

Our methodological framework is informed by a review of

general and climate-specific PE literature by practitioners and

multilateral institutions (Corduneanu-Huci et al. 2013; Whaites

2017; Vogt-Schilb and Hallegatte 2017), think tanks (Moncrieffe

and Luttrell 2005), and academics (Inchauste et al. 2018).

Nearly all frameworks we reviewed included structural and

institutional elements as well as an analysis of stakeholder

interests, incentives, and power relations. However, only a

few emphasized the role of ideas and narratives, which can

shape worldviews, social and individual identities, and how

decision-makers perceive the problem and potential solutions

(Rodrik 2014). Other recent climate governance assessments

have confirmed the importance of narratives and ideas in

understanding and responding to climate risk (Shakya et

al. 2018). Our assessment framework was contextualized to

the climate policy arena based on a review of the climate

governance literature and conversations with colleagues, and

a review of commitments related to climate governance by

members of the Open Government Partnership. The framework

was further developed through workshops and small group

discussions at World Resources Institute before it was

reviewed and revised based on comments from 30 experts

from government, civil society, and multilateral organizations.
Based on the answers to these questions, users could organize, for example, a consultative workshop or a few small group discussions with stakeholders who can help validate the governance challenge and identify resources and interview targets (see Step 3 of Figure 1). The set of stakeholders may include current or former government officials, NGO staff, grassroots leaders, and academics. ${ }^{18}$

While the majority of stakeholders should have policy or political experience on the climate governance issue at stake, in some cases, users may wish to invite experts on other issues with climate co-benefits, who may become more engaged in the future. These participants may also be viewed as key messengers for the eventual output. ${ }^{19}$

The scope of the analysis should ultimately be determined by users based on the identified or anticipated problem. Users should review the assessment questions to determine those that are most relevant to the challenge and which may be resolved, or partially resolved, through discussions, workshops, or other forms of engagement with key experts and stakeholders at the outset. Other questions are likely to require desk research and will almost certainly require interviews or informal discussions with experts.

\subsection{Identifying the Governance Challenge}

All countries face the climate challenge of setting and meeting GHG reduction targets that will collectively achieve net-zero carbon dioxide emissions (global average) by 2050 and net-zero total GHG emissions by $2063-$ 68. ${ }^{20}$ These reductions must be achieved while ensuring a just transition ${ }^{21}$ and building resilience across society (Levin and Davis 2019). Numerous potential governance and $\mathrm{PE}$ challenges must be addressed given the multiscale and multisector nature of climate action. Users of this assessment should consider how addressing the challenge they identified can plausibly contribute to raising the overall ambition of their country's climate actions or improving the enabling environment for effective and equitable implementation. A few examples of common governance challenges are provided in Table 2. 


\section{Box 6 | Tips on Carrying Out the Assessment}

The ideas behind this assessment might resonate but the task of undertaking research can seem daunting. Teams may have limited capacities, funds, or bandwidth; incorporating findings into daily work can appear difficult. Yet, even when resources are slim using the assessment to encourage politically smarter approaches is feasible:

1. Just get started: While the assessment is there to guide, it does not have to be followed to the letter. Try breaking it up, investing first in those areas for which capacity is already available and feel most relevant to your challenges. Customize your approach. Try first going through a process to define where problems lie, or look at stakeholder mapping. Build confidence and knowledge in order to commission deeper analysis or plan to do more internally.

2. Form a team: Put together a team to work on climate governance challenges and incentivize their involvement. This could be a learning opportunity, even forming part of a training program. Establishing a team will also ensure greater consistency and retention of knowledge as you build your assessment.

3. Utilize diverse, country-based knowledge: Country staff have considerable understanding and knowledge that is invaluable in designing politically smart approaches. Make sure that you look beyond the technical experts to diversify knowledge in your team. Drivers, administrative staff, and security guards will all have relevant PE perspectives.

4. Encourage broad participation: To the extent feasible, the assessment should engage with a group that is as diverse as possible. Certainly, try to achieve a gender balance, but also think about ethnicity and class as well as culture and religion. Bring these considerations to your team as well as to the people with which the team interacts.

5. Write everything down: It is important to always record discussions; talking through the assessment will build internal knowledge but committing to the record will enable the team to use analysis to influence practice. Highlight areas where it would be beneficial to have more information, areas for which sensitivities are high, and areas that appear particularly relevant to the context.

6. Closely consider sensitivities: Considering political issues and doing so openly can raise sensitivities. In some contexts, there can be actual physical risks associated with "going against the grain" of dominant ideologies. Consider this closely at the outset and put in place restrictions; hold closed-door discussions, use the Chatham House Rule, restrict circulation of analysis, and only share more widely information that is suitable. Ensure that all team members understand and agree to the risks.

7. Be reflective: Team members undertaking an assessment will inevitably have their own agendas, views, and sensitivities. Make sure that you reflect on this in your team and consider how you manage so as to limit bias in your analysis.

8. Use PEA momentum: The output of team sessions can be utilized to create further awareness of and support for the assessment, including through generating senior support.

9. Continual and iterative: Rather than aiming for a standard report as an output, try to aim toward a customized process that continues over time and is developed with the team iteratively. If you commission governance or political economy experts for support, embed them in your team and ensure that their ToR reflects any learning needs. If possible, plan their involvement over a suitable period of time rather than in one report-writing burst.

Source: Authors 


\section{ISSUE AREA \\ POLICYMAKING CHALLENGES}

Mitigation ambition Adaptation
ambition

Equity

Coordination

Transparency

and

accountability from government officials balance of power powerful officials
- Key sectors are exempt

- Targets are not in line with Paris goals or there is no mechanism for review and ratcheting

- No cross-sector coordination mechanism in place

- Climate policy is in place but remains a low priority and insufficiently funded

- Proposed policies have stalled or fallen off lawmakers' agenda

- Existing policies, like fossil fuel and water subsidies, contradict NDC-aligned policies

\section{IMPLEMENTATION CHALLENGES}

- Lack of compliance or enforcement leads to implementation falling short of policy aims

- Lack of implementing rules, guidance, or knowledge at local government levels

- Limited accountability and oversight at local government levels leads to conflicts of interest, fraud, corruption, etc.

- One-size-fits-all approaches to policy development and implementation alienates local actors

- Reorganization of government agencies has weakened the agenda for implementation or removed institutional knowledge

- Planning practices and public investment are not aligned with climate-risk scenarios

- Rent-seeking by officials at sector, planning, or local level leads to misuse of adaptation funds

- Lack of protocols or incentives for coordination at the sector level

- Lack or misuse of social and environmental assessments or other tools to assess equity in implementation

- Monitoring and evaluation have not been systematically integrated or results do not have political salience

- Data collected from evaluations are manipulated and politicized, so their utility is limited

- Climate policies do not produce strong enough incentives to counteract embedded social inequalities

- To be enacted, climate policy is diluted to maintain the existing

- Policies are conceived separately and are not integrated into major sectors, missing out on opportunities to address equity

- Framework policies or sector commitments lack the buy-in of

- Inter-ministerial committees on climate have not been established, are not adequately budgeted, are not staffed by officials with decision-making power, or lack authority to compel implementation of decisions

- Lack of an independent oversight institution to monitor, assess, and report on progress

- Poor capacity of implementing agencies (understaffed, underbudgeted) to implement changes

- Implementing agency leadership do not see themselves as accountable to climate policy goals

- Measurement, Reporting, and Verification (MRV) system lacks transparency on indicators to assess implementation and impact of policies 
Conceptualizing the governance challenge in detail can help direct focus where technical analysis and engagement have failed to gain operational traction in the past (Fritz et al. 2014).

Given the breadth of potential challenges in climate change governance it is worth spending some time at the outset reflecting on what underlying issues might relate to the challenge. Users should consider inviting stakehold- ers who may have different perspectives based on their background or sector expertise to validate the challenge. In countries with significant sociocultural and geographic diversity, users should consider whether the problem may be perceived differently by different people. Table 3 presents questions to guide users in reaching consensus on the scope and scale of the climate governance challenge selected for analysis.

\section{Table 3 | Clarifying the Nature of the Challenge}

\section{QUESTION}

Have previous attempts to introduce reforms, change policy, or otherwise implement climate actions been opposed?

Is adopting climate laws and policies expected to be challenging, or is the primary concern the implementation of these frameworks, or both?

How did this issue become apparent? Was it precipitated by new climate commitments or more longstanding?

What is the governance scale of the problem-national, subnational, or multiscale (e.g., coordination, cooperation, information sharing between authorities or actors at different scales)?

Is the problem related to a specific sector or crosscutting?

Is the governance challenge specifically related to either adaptation or mitigation policies?

Is this governance problem threatening to undermine climate ambition in your country? If so, how?

Is there anyone (groups or individuals) who may disagree with this assessment of the problem and, if so, why? Consider gathering their input during the research to triangulate information.

\section{PURPOSE}

There may be useful evidence highlighting where and why prior reforms failed to gain support. Previous experience can be very helpful in anticipating the range of challenges that may result from advocating for a particular reform and help strategize ways forward.

Different governance stakeholders are concerned depending on whether the challenge is adoption or implementation. For the former, parliamentarians and national decision-makers, as well as the incentives driving their decisions, may be the primary focus. If the latter, then the issues may be more localized, potentially to local levels of government or the interaction between local government and the community.

This can help to determine whether ideas, incentives, and institutions have become more receptive to climate change actions or less so over time. It may be that more recent ideas, circulating in the media, have reduced opposition to climate reforms. Or the opposite could be the case. Estimating how ideas have changed over time can be helpful in anticipating the impact on institutions and incentives.

This helps determine the relevant decision-makers, stakeholders, incentives, and policy venues, It may be worth sequencing assessments to look particularly at the PE factors driving national climate governance first before looking at local or multiscale challenges. It is also worth considering that in many contexts, particularly under federal arrangements, local PE factors may be markedly different from national factors.

This question also helps establish scope. In some cases, users may broaden or narrow the scope based on information uncovered. A common issue with climate governance is that it often requires extensive crosssector coordination, which can be difficult depending on the institutional culture of government. Hierarchical cultures, those with low participation and those that limit political competition, may pose particular difficulties in this regard. Another common issue is balancing the demands of various stakeholders with opposing objectives; even in a single sector-for example, water-this is likely to be an issue.

Legal and policy frameworks, decision-makers, incentives, and narratives may vary between the two. There are also issues (such as energy access) where they intersect.

There are a number of reasons to reflect on this question. Depending on the composition of the team undertaking the assessment, there may be certain dominant viewpoints, objectives, and ideas. It is worth considering this, and rebalancing the team if, for instance, there is too little gender or ethnic diversity. It can also be helpful to think through which aspects of the challenge are subjective or who may have interests opposed to governance change.

This can help to determine whether ideas, incentives, and institutions have become more receptive to climate change actions or less so over time. It may be that more recent ideas, circulating in the media, have reduced opposition to climate reforms. Or the opposite could be the case. Estimating how ideas have changed over time can be helpful in anticipating the impact on institutions and incentives. 


\subsection{Dimensions of the Assessment}

Once a challenge has been defined and unpacked as much as possible, a cycle of analysis can begin. This section introduces four elements of PEA:

Structural factors that influence the type of climate governance available; these factors are slow to change and most likely will need to be adapted to or worked around to implement climate actions.

Formal and informal rules, procedures and ways of working that will influence aspects like implementation of the applicable legal framework.

Stakeholders, including individuals and groups who may influence and hold power over the adoption and implementation of climate actions.

Ideas that hold power and influence climate change narratives.

Users can turn to different sources of information, depending on the challenge identified. Legal frameworks, such as the constitution, are relevant for established procedural and substantive rights. Framework environmental and climate laws are generally used to set targets, create decision-making structures, assign responsibilities, and establish fiscal mechanisms. Sectorspecific regulations specify policy mechanisms, standards, and protocols that help to achieve targets. Also potentially relevant are administrative laws that govern information request and disclosure procedures, public participation, grievance, and redress.

National Communications to the UNFCCC often provide an overview of relevant policies, as do multiple online climate law and policy databases. ${ }^{22}$ While most governance questions are aided by establishing a precise understanding of obligations and enforceable provisions, not all assessment questions will be relevant to all users, or users may quickly determine that there are few relevant binding rules. Legal analysis can be time-consuming, so users should determine what type of additional clarity is needed that cannot be retrieved from reliable secondary sources.

Informal rules and norms are unlikely to be documented and are best obtained through interviews with former government officials, politically astute civil society members, journalists, or academics. Current government officials may feel too constrained to give forthright responses to these questions, particularly if the responses contradict formal rules. Given the degree of subjectivity, researchers should corroborate responses and indicate where there is disagreement (while ensuring confidentiality).

\subsubsection{Element 1: Structural factors}

Unsworth (2007) describes structural factors as "factors that fundamentally shape the state and political system," and includes "territorial integrity, the history of state formation, the revenue base, socio-economic structures, the geostrategic position, and geographic aspects of the country." These factors can and do change over time, but for the most part they will need to be accommodated, rather than confronted, when planning reforms.

Knowledge of structural factors is likely to be high among domestic climate advocates, but putting them together and considering their impact on a climate challenge is still important. The process is likely to refresh perspectives and reinforce knowledge. International advocates with limited knowledge of country contexts should work to understand structural factors as a crucial first step in appreciating how they influence plans for climate adaptation and mitigation.

In any given situation there will be a wide range of structural factors; it is important to assess only those factors that are directly relevant to the climate governance challenge under consideration. Be as selective as possible and do not try to be exhaustive. Box 6 summarizes the types of issues addressed through the structural questions. See Appendix A for a detailed set of questions.

\subsubsection{Element 2: Rules and norms}

Once users have analyzed the relevant combination of structural factors, it's then important to identify the rules and norms. Assessment questions address the state of formal requirements that establish responsibilities and expectations for the functions and practices of public authorities. While non-exhaustive, these questions will help identify whether insufficient or unclear rules and mandates may be contributing to governance problems. On the other hand, if formal rules are well-defined and cover climate-related decision-making, these questions may help users focus on the informal norms, incentives, and capacity building to create conditions that are more conducive to implementation. Informal factors influencing climate governance will include the "unspoken rules and norms" adhered to by a ministry or an implementing party and can include implicit acceptance of how things work in reality that is different from the formal guidelines or rules. 


\section{Box 6 | Structural Factors}

The assessment questions cover structural factors that are relevant to a PEA of any issue, as well as ones more likely to influence climate change decision-making. Issues touched upon include:

- Exposure of the country to different climate change impacts

- Level of public debt (which may influence decisions to shift away from high-carbon investments)

- Demographic trends, such as population growth, percentage of youth and/or seniors, ethnic diversity, urbanization, and geographic concentration

- Levels of inequality

- Political conditions, such as independence of branches of government, decentralization, single-party or multiparty systems

- Domestic energy resources, their contribution to the economy and employment, and ownership

- The capacity and ability of civil society to participate in and influence climate policies, including historical representation and issues of trust with public authorities

Source: Authors

Informal rules and norms may affect the way certain processes, like recruitment or procurement, are actually conducted, expectations about who will make decisions and when, and acceptance of "things working differently" in some parts of the country versus others because of local traditions or cultures influencing implementation. In a climate governance context, it may mean that the decisions produced by a newly created intragovernmental coordination committee may rely on the support or buy-in from a political party leader or a well-connected ministry official whose sector-agriculture, for instanceincludes a significant constituency of the ruling party. It may also mediate how capacity-building efforts lead to organizational change at the agency level. Box 7 summarizes the issues covered by these questions. See Appendix B for a more detailed set of questions.

\section{Box 7 | Rules and Norms}

The assessment's questions on rules and norms cover formal mandates and structures as well as informal norms based on historical practice, relationships, and power dynamics. The issues addressed include:

- The level of decision-making power at which the climate policy issue of importance has been prioritized, and whether this is consistent with where action is needed

- The presence and number of veto points in policy enactment, and how climate action opponents are likely to use them

- The presence of overlapping or conflicting mandates which may impact implementation

- The type and source of capacity gaps that constrain action

- The culture of key government agencies, including historical mandates, culture, relationships with non-state actors, and other informal factors that influence behavior

- Transparency of decision-making

- Sociocultural norms that inhibit involvement of certain groups or shape power dynamics in civil society's influence on policymaking

- The structures, incentives, relationships, and power dynamics that influence the effectiveness of horizontal (across government) and vertical (national-subnational) coordination

- Rules and incentives that may be in place to promote policy coherence

Source: Authors

\subsubsection{Element 3: Stakeholders and interests}

Stakeholders include individuals, networks, or constituencies who may participate directly in decision-making processes as well as those who are excluded. Stakeholders may be highly organized, such as political parties, unions, business lobbies, or citizens' groups, though they may or may not see climate policy as relevant to their interests. In some cases, there may be stakeholder groups organized around an issue such as food security or pollution, which may not have historically seen climate change as relevant, but which could be more engaged in policy development. Stakeholder analysis should also enable researchers to 
delve into the underlying interests behind opposition or reluctance on the part of decision-makers. For instance, decision-makers may feel that expending political capital on climate policy would distract or reallocate resources from other priorities. They may fear that taking on a particular vested interest would disrupt a fragile alliance that is important for accomplishing another policy objective.

Incentives can prompt behavioral change in elected or appointed officials to support policy development or implementation if they appeal to individual or collective interests. In countries where the rule of law is strong and there are effective lines of accountability, a new legal mandate-for instance, to enforce emissions reduction targets in transport-may be sufficient to shift sector policies, spur capacity building, and measure performance differently. However, in a different country context, fossil-fuel-intensive industries, large-scale agriculture, or other incumbent interests may have an outsized influence on regulatory authorities and be able to effectively delay or weaken implementation. If cabinet officials are politically interested in seeing the law implemented effectively, they may ensure that new performance metrics established to ensure personal incentives are aligned with new mandates to implement climate actions.

Stakeholder mapping should provide a political analysis of the interaction of interests and identify key actors, as well as their intentions, strategies, resources, and actions, and the outcomes of those actions. The assessment should also include a historical perspective to understand how interests come to be dominant in which policies and why, and thus be able to predict how climate policies can be structured and advocated for among the different stakeholders. Box 8 summarizes the issues covered by the Stakeholders and Interests questions. See Appendix C for a detailed set of questions.

\section{Box 8 | Stakeholders and Interests}

The stakeholders and interests questions assess key actors and stakeholder groups, their underlying interests, and their incentives in supporting or opposing the climate policy in focus. In situations where users have already conducted a stakeholder mapping, the results could inform these

questions. Topics include:

- The non-climate benefits of potential climate policies and whether and how they are recognized by different stakeholder groups

- The degree to which the executive branch exerts power across branches of government and over subnational actors

- The prevalence of patronage in prioritizing policies and their beneficiaries

- Identifying key decision-makers, the actions they need to take, and the constituencies that influence them

- The distributional impacts of a potential climate policy on different stakeholder groups and whether and how these groups are organized in support or opposition

- The degree to which civil society or certain groups face threats directly from government or governmentsanctioned actors that may limit their participation or effectiveness

- Whether recent government reorganization provides a window of opportunity to shape the political agenda or engage non-state actors in new ways

- How system shocks-such as the COVID-19 pandemichave exacerbated vulnerabilities and whether government responses present opportunities to address climate change in ways that were not politically feasible before 


\subsubsection{Element 4: Ideas and narratives}

Ideas and narratives refer to the ideas and framing of the problem and the set of solutions that are commonly deemed to be plausible or desirable. The way in which problems and policy solutions are described and linked to prevalent ideologies, cultural values, or histories is likely to influence their ability to gain traction and support (Repetto 2006). Schmitz (2016) has shown that recent clean energy policy reforms in multiple countries were driven by concerns about energy security, job creation, and growth of new industries, rather than climate change. Framing of the problem matters because it affects how people assess what solutions are relevant and viable. Box 9 summarizes the issues addressed. See Appendix D for a detailed set of questions.

\section{Box 9 | Ideas and Narratives}

Ideas and narratives can shape what policymakers and stakeholders see as the problem and potential solutions or limit the effectiveness and equity of climate action. The assessment questions cover the following topics:

- Prevailing idea(s) on how the problem should be addressed, how they are affecting climate action opportunities, whether they are linked to an ideology, and how they are promoted

Whether there are competing ideas and how they are being promoted

- The dominant narrative on climate change risks, the role of equity in considering actions, who's responsible, and what can be done as well as how the narrative influences political action

- How the issue is framed in the media and the role of key messengers in shifting the dialogue for targets of influence

Source: Authors

\section{MAKING SENSE OF THE RESULTS}

The purpose of this exercise is to provide domestic climate policy advocates and practitioners with a framework for considering how PE factors enable or impede the governance of climate policies. While research using the questions may confirm preexisting assumptions or understanding, it may also reveal new and possibly unexpected information or prompt users to consider different ways of approaching stubborn problems. For example, users might build coalitions with new interest groups, strengthen rules to promote accountability, or build the capacity of oversight institutions. The assessments generated by this guide should contribute to shaping the action of users; ideally, they should be used to shape interventions, consider risks, and check assumptions. The following set of steps can be adapted by users based on what they think will best reach partners and target audiences:

\section{Develop and share an internal draft to generate} discussion and agree upon next steps. Following the process outlined above will have provided a substantial amount of information. The output need not be a report-a presentation may suffice. A summary for an internal audience should seek to highlight the following:

A short account of the challenge that was the focus of inquiry and why it was selected (e.g., how its resolution could unlock greater climate ambition, more accountable implementation, greater equity in climate actions, etc.).

An overview of the domestic "landscape" of climate governance, as relevant, including major NDC commitments, focal point agencies, or recent legislation.

Key points that have emerged from research on the four elements, highlighting the most valuable information as well as why this information is thought to be valuable. For instance, it's useful to clarify divergence between formal rules and expectations and practice. It's also important to note the possible reasons, which might include disincentives to following the rules, corruption, or abuse of power, or simply pragmatism on the part of implementers when trying to make policy fit a local context. 
Note any disagreements in response caused by, for example, certain respondents having a better vantage point to understand decision-making, lack of clarity, or conflicting motives, or a situation that is in flux.

Any developing storylines, such as a new mandate requiring coordination between agencies that historically haven't cooperated well, a lack of clear incentives for collective action, or ineffective oversight.

Based on this draft, it's also valuable to reflect on the following questions:

Are there priorities that should be addressed first before other issues can be dealt with?

What are the risks of confronting potentially deep-seated vested interests directly, and are more circuitous routes available to create change? For instance, are there policy design, framing, or implementation strategies that can minimize confrontation, reduce veto points, or mitigate the influence of these interests?

Has unexpected or new information changed objectives or introduced different objectives? If appropriate, does this impact a theory of change or other rationale justifying programming?

Can actions be taken in the near term that would unlock greater political ambition (by producing policy benefits, creating employment, and thus creating political constituencies)?

Consider sharing and validating the results with the initial workshop participants. It may be useful to include visuals to display relationships and influencing factors.

Based on the results and subsequent discussion, consider what, if any, strategic shifts should be made to improve the likelihood of commitment, accountability, or effectiveness. Have the targets of influence changed at all and which stakeholders are best equipped to take the next steps?

What are plausible next steps? Are there upcoming opportunities to leverage action?
The last step should look at possible pathways forward to address the identified climate governance challenge. What does the inquiry tell us about what's possible, and what's not? Are "quick wins" to build confidence among stakeholders feasible? Are there issues that should be avoided, at least directly? Which stakeholders might be more influential on climate issues than first thought? Would broad coalition-building be helpful? What do we still need to know that a closer examination may help to reveal?

Fundamentally, supporting effective climate governance is about encouraging transformational change. The clearer the context, the more exposed the underlying influences, the more supported the coalitions that lead local climate action-the greater the likelihood of enduring change.

\section{CONCLUSION}

The world is currently off track to meet the temperature goals in the Paris Agreement that, if achieved, would minimize the human suffering and immense economic, social, and ecological costs that will result from unchecked climate change. As countries revise and enhance their NDCs, a wide range of stakeholders-including decisionmakers, civil society, and donors-need a sophisticated understanding of the political and governance challenges that different climate actions are likely to encounter. With these insights, they can focus on appropriate national remedies, based on what is possible-whether strengthening rules, broadening coalitions, empowering oversight authorities, or even carefully designing policies to deliver visible benefits that will make them harder to overturn.

We developed this assessment and guidance to provide a more systematic framework for domestic stakeholders to understand the PE dimensions of potential climate actions. We hope that this will inform policy design, implementation strategies, capacity building, and advocacy. We acknowledge that PE tools exist and some actors may already be using them, but we see little in the way of guidance for climate advocates. WRI will pilot this assessment with partners in India and Brazil in 2020-21 to inform climate strategies for NDC implementation and enhancement. 
Table A1 | Questions on Structural Factors

Structural factors: Political, social, environmental, and economic conditions that are unlikely to change in the short term

\begin{tabular}{|c|c|}
\hline $\begin{array}{l}\text { STRUCTURAL } \\
\text { FACTOR }\end{array}$ & $\begin{array}{l}\text { ASSESSMENT } \\
\text { QUESTION }\end{array}$ \\
\hline $\begin{array}{l}\text { Climate } \\
\text { exposure }\end{array}$ & $\begin{array}{l}\text { What are the major climate } \\
\text { risks for your country (or } \\
\text { state)? Which industries, } \\
\text { social groups, assets, or } \\
\text { livelihoods are most likely to } \\
\text { be affected? }\end{array}$ \\
\hline $\begin{array}{l}\text { Economic } \\
\text { conditions }\end{array}$ & $\begin{array}{l}\text { What (if any) factors restrict } \\
\text { growth, investment, and } \\
\text { employment? What sectors } \\
\text { are most important for the } \\
\text { national economy? }\end{array}$ \\
\hline $\begin{array}{l}\text { Public sector vs. } \\
\text { private sector's } \\
\text { role in the } \\
\text { economy }\end{array}$ & $\begin{array}{l}\text { What is the share of public } \\
\text { vs. private ownership in the } \\
\text { country? What share of GDP } \\
\text { are public expenditures and } \\
\text { tax revenue? }\end{array}$ \\
\hline
\end{tabular}

tax revenue?
GUIDANCE

Consider any national vulnerability assessments, UNFCCC national reports, work of academics or think tanks

Economic conditions can shape the level of development and how demands for growth impact the environment, and the potential for socioeconomic factors to influence climate actions, through special interests, fears of job losses, etc.

Particularly for investments in lowcarbon infrastructure and energy, this factor can determine the extent to which monopolies dominate power production and influence effectiveness.

\section{Level of public debt}

Has the government taken on significant public debt to finance carbon-intensive infrastructure?
Mitigation-sunk costs in energy infrastructure may impact willingness to shift rapidly away from carbon-intensive energy production.

Demographics

Is the population growing? Is there a high percentage of youth ("youth bulge") or seniors? Is there a diverse mixture of ethnicities? Are people located more in rural or urban areas? Is there a higher concentration of people in some parts of the country relative to others?
A growing population may indicate pressure on resources; youth bulge increases the demands on education and employment and may also represent a growing interest group for climate; more seniors requires greater investment in health services and potential for low economic productivity; diverse ethnicities may mean a variety of cultural and religious perspectives and traditions; geographic distribution of population may affect which groups are prioritized for investment.

\section{OUTPUT}

Answers can inform who potential interest groups and stakeholders may be Biennial Update Reports, national adaptation plans

\section{SOURCES}

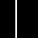

nationa adaptation plans
Brief summary of overarching conditions that are likely to have a bearing on political interests

Relevant for understanding where investment in lowcarbon, climate-resilient infrastructure is likely to come from, as well as an indication of investment in the social safety net, as countries with a higher proportion of public expenditure are more likely to invest there.

Risk of debt defaults if revenue falls may influence political decisions to shift away from these investments, particularly if there is strong regulatory capture.

Brief summary on demographic trends to inform stakeholder mapping, decision-maker interests, and narratives and values for climate action 


\begin{tabular}{|c|c|}
\hline $\begin{array}{l}\text { STRUCTURAL } \\
\text { FACTOR }\end{array}$ & $\begin{array}{l}\text { ASSESSMENT } \\
\text { QUESTION }\end{array}$ \\
\hline $\begin{array}{l}\text { Social, } \\
\text { economic, } \\
\text { and political } \\
\text { inequality }\end{array}$ & $\begin{array}{l}\text { What is the degree of } \\
\text { multidimensional inequality } \\
\text { at the national (or state) } \\
\text { level? Has the trend been } \\
\text { worsening or improving? } \\
\text { How does it intersect with } \\
\text { gender, ethnicity, or other } \\
\text { social identity, rural/urban, } \\
\text { education level, etc.? }\end{array}$ \\
\hline $\begin{array}{l}\text { Territorial } \\
\text { sovereignty }\end{array}$ & $\begin{array}{l}\text { Are there disputed territories } \\
\text { or challenges to national } \\
\text { public authority that prevent } \\
\text { tax collection or application } \\
\text { of judicial systems? }\end{array}$ \\
\hline
\end{tabular}

\section{GUIDANCE}

This informs equity considerations, climate vulnerability, historical legacies of exclusion, potential political priorities for development. If there is a backdrop of growing inequality, the social contract may be in question and there may be social movements coalescing around this issue.

As this is basic political economy, this information may be available from secondary sources or past political economy overviews.
OUTPUT

Identification of drivers and trends of social and economic inequality

\section{SOURCES}

Multidimensional Inequality Framework (Atlantic Fellows for Social and Economic Equity 2019)
Legitimacy of the nationstate and ability to collect revenue
Afrobarometer for Africa, World Bank's Worldwide Governance Indicators (WGI), World Justice Project Indicators, aid donors' and international multilaterals' country assessments and program plans, project documents for specific governance interventions Peer-reviewed literature in social sciences, input of a relevant academic, national census data, local academic research, religious organizations, cultural organizations

\section{Cultural and religious conditions}

To what extent do religious or cultural values shape public debate around climate change risks and solutions? Is there a plurality of religious and cultural perspectives or is society dominated by a single religious belief and/or cultural narrative?
This information may be gathered from relevant social science literature or an interview with a sociologist or similar expert.

Countries with domestic fossil fuel supplies tend to face greater politicaleconomic challenges shifting to low-carbon sources; the duration that these resources have been exploited often influences how entrenched these industries are in the politics of regulation.
Shed light on whether prevalent religious and/or cultural views are likely to influence social attitudes to climate change, mitigation measures, and adaptation, and, if so, in which ways.
Description of the nature and composition of domestic fossil fuel industries
National energy policy documents, International Energy Agency (IEA) reports, World Bank statistics 
Table A1 | Questions on Structural Factors (continued)

\begin{tabular}{|c|c|c|c|c|}
\hline $\begin{array}{l}\text { STRUCTURAL } \\
\text { FACTOR }\end{array}$ & $\begin{array}{l}\text { ASSESSMENT } \\
\text { QUESTION }\end{array}$ & GUIDANCE & OUTPUT & SOURCES \\
\hline Civil society & $\begin{array}{l}\text { How effectively is civil } \\
\text { society able to influence } \\
\text { the public debate and } \\
\text { policymaking specifically? Is } \\
\text { there a cultural expectation } \\
\text { and historical legacy of } \\
\text { civil society engaging in } \\
\text { policymaking? Are there } \\
\text { major trust deficits between } \\
\text { the government and civil } \\
\text { society generally or with any } \\
\text { specific social group? }\end{array}$ & $\begin{array}{l}\text { The purpose is to understand whether } \\
\text { the media and civil society are able to } \\
\text { hold government to account without } \\
\text { fear of deregistration, loss of funding, } \\
\text { imprisonment, or violence. Historical or } \\
\text { present-day discrimination may cause } \\
\text { different social groups to experience } \\
\text { this differently. }\end{array}$ & $\begin{array}{l}\text { Understanding of the } \\
\text { enabling environment } \\
\text { for policy monitoring and } \\
\text { accountability to public } \\
\text { interests }\end{array}$ & $\begin{array}{l}\text { International development } \\
\text { organizations' governance } \\
\text { assessments, civil } \\
\text { society support projects' } \\
\text { documentation }\end{array}$ \\
\hline Conflict & $\begin{array}{l}\text { Is there a legacy of conflict? } \\
\text { What is the nature of the } \\
\text { conflict? What are the main } \\
\text { drivers of internal conflict } \\
\text { (e.g., land competition, water } \\
\text { access)? Are there threats } \\
\text { of regional instability or } \\
\text { a threat from an external } \\
\text { power? }\end{array}$ & $\begin{array}{l}\text { Underlying factors of vulnerability- } \\
\text { interest group alignment, trust } \\
\text { in government, and post-conflict } \\
\text { situations-may affect the stakes of } \\
\text { national dialogue on climate action } \\
\text { and influence the narrative on climate } \\
\text { change }\end{array}$ & $\begin{array}{l}\text { Relevant considerations } \\
\text { for how recent or ongoing } \\
\text { conflict will shape political } \\
\text { debate, stakeholder } \\
\text { relationships, or policy } \\
\text { options }\end{array}$ & $\begin{array}{l}\text { International Crisis Group, } \\
\text { UN archives, Carnegie } \\
\text { Endowment for International } \\
\text { Peace, Brookings Institution, } \\
\text { local media, local academia, } \\
\text { international development } \\
\text { organizations, humanitarian } \\
\text { organizations (especially for } \\
\text { IDP data) }\end{array}$ \\
\hline
\end{tabular}

Source: Authors 
Table B1 | Questions on Rules and Norms

Rules and norms: These include formal laws and regulations as well as informal norms that shape interactions between actors and generate incentives and constraints.

\section{\begin{tabular}{l|l} 
CATEGORY & ASSESSMENT QUESTION
\end{tabular}}

$\begin{array}{ll}\text { Political } & \text { Are the executive, parliamentary, } \\ \text { conditions } & \begin{array}{l}\text { and judicial branches of government } \\ \text { independent and functioning? Is there a } \\ \text { credible multiparty political system or is } \\ \text { it dominated by one party in practice? To } \\ \text { what degree is power decentralized? }\end{array}\end{array}$

\section{GUIDANCE}

As this is basic political economy, this information may be available from secondary sources or past political economy overviews. While this is listed as foundational (not likely to change soon), in some countries this may be in flux (e.g., shifts toward more open or authoritarian regimes, greater or lesser decentralization).

\section{OUTPUT}

Basic framing of political institutions and power structures

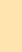

$\begin{array}{ll}\text { Agenda } & \text { Which level of decision-making is } \\ \text { setting } & \begin{array}{l}\text { prioritizing solving this problem and is } \\ \text { there a disconnect between high-level } \\ \text { statements and agency actions? For } \\ \text { example, department-level, ministerial- } \\ \text { level, prime minister/head of state or } \\ \text { other? }\end{array}\end{array}$

$\begin{array}{ll}\text { Policy } & \text { At which veto points are organized } \\ \text { enactment } & \begin{array}{l}\text { opposition likely to attempt to thwart or } \\ \text { weaken the proposed policy? }\end{array}\end{array}$

Agency Formally, which government authority/ mandates
This is not only about whether there are high-level statements of support, but also whether there is evidence that this is influencing priorities of implementing agencies. Look for plans, policies, or investments that support or contradict public positions. To understand the depth of political support, understand targets of influence. Also consider whether this may be in flux due to recent or upcoming elections, ministerial reorganizations, or other shifts in power.

Veto points are institutional thresholds that a policy must pass to be enacted. Some countries have more than others (bicameral legislatures, federal decision-making, presidential vetoes, etc.). Users should consider which veto points are most prone to organized opposition and weigh the advantages of coalition-building, tweaks in policy design, or shifting to a different policy venue.

To begin the assessment of implementation failures, understand formal responsibilities. Consider whether the mandate is recent or lacks political or legal oversight.

\section{A clearer sense of the level of decision-making that may be lacking incentives or capacity to address the problem}

\section{SOURCES}

Global and regional governance indicators from multilaterals and NGOs, project documents for specific governance interventions Policy documents, interviews, public statements, regulations, budgets

\author{
More detailed Interest group \\ understanding of and stakeholder \\ where opposition mapping \\ is likely to organize \\ will inform \\ advocacy strategy
}

Identify formal obligations relevant to resolving the challenge that are not being fulfilled
Law, decree, or policy documents this issue? Is there a mandate that establishes responsibility to carry out an action which has not been fulfilled? If so, briefly describe. If the expectation has not been created through law or decree, describe how it has been established.

$\begin{array}{ll}\text { Agency } & \text { Are there conflicting mandates for the } \\ \text { mandates } & \begin{array}{l}\text { implementing agencies or domain } \\ \text { overlap with another authority's } \\ \text { responsibility? If so, describe. }\end{array}\end{array}$

Depending on the accessibility of information, users could start with interviews and corroborate with desk research.
Potentially relevant background on why new mandates have failed
Law, decree, or policy documents; interviews, if needed 


\section{CATEGORY ASSESSMENT QUESTION}

Agency In practice, are there other authorities

mandates that have more power and influence? If

so, from what sources is this influence derived?

\section{Capacity If there are underlying capacity constraints constraints (e.g., budget, staffing, technical capacity, etc.), what is the reason that resources have not been provided to fulfill the mandate?}

\section{Agency How are historical legacies-previous} culture mandates, organizational structure, leadership, and key constituencies, etc. - influencing the behavior of this actor (ministry, agency, etc.) today?
Is there evidence based on rules, enforcement, or other observed behavior, of regulatory capture? If so, how might this affect policy development and implementation regarding your issue area?

\section{Information If the problem is mitigation-oriented,} asymmetries how accessible is relevant information on sources of emissions, trends, mitigation measures adopted, progress in implementation, and resulting impacts?

\section{Information \\ If the problem is adaptation-oriented, asymmetries on climate risks, vulnerability, adaptation options, finance, and implementation and impacts?}

\section{OUTPUT} SOURCES

\section{GUIDANCE}

In some cases, there are nominal authorities and more powerful organizations or actors that can enable or constrain implementation.

A failure of the international community to mobilize finance may contribute to these deficits, but users should assess whether political choices played a role in staff hired, capacity developed, or budgets allocated. It will be important to corroborate responses between different sources as there may be disagreement and lack of access to information.

Identifying these causes can help identify capacity building or new incentives that may be needed. This information may be available in secondary sources or from key experts consulted at the outset.

Potential examples are agency rules and guidelines aligned with industry position statements, lack of transparency on staffing decisions, and rulemaking.
For more guidance on this and other climate policy implementation tracking see Barua et al. (2014). The purpose is to build on previous questions to specify what type of information should be made accessible.
Users may tailor this question to the information that they are seeking. Is the problem one of fragmentation, poor disclosure, lack of usefulness, or otherwise? The source of the disclosure problem may have to be addressed through interviews.
More strategic targeting of

oversight, accountability, or capacity building

Insight into the political and institutional hurdles to capacity building
Key context that may explain present-day interactions between agencies or resistance to behavioral change

Determination of potential procedural mechanisms to push for more accountability

Specific information related to tracking implementation

that would enable better accountability and oversight

Sharpened strategic goals for advocacy related to transparency and accountability of adaptation
Political science literature, interviews with academics, or former authorities

Interviews, investigative journalism, public documents

Desk research

Interviews Interviews, direct observation 


\section{CATEGORY ASSESSMENT QUESTION}

Transparency Is there a lack of transparency that is hindering decision-making? If so, at which point in the decision-making process and who is responsible?

$\begin{array}{ll}\text { Decision- } & \text { Are there legally binding requirements } \\ \text { making } & \text { for public participation in climate } \\ \text { procedures } & \text { decision-making? How well are these } \\ & \text { being implemented in practice? }\end{array}$

Decision- Based on previous experience, are these making formal procedures viewed as legitimate norms

\section{Decision- making norms}

If there are social, religious, or cultural norms that inhibit the participation of certain groups, is there political support to change these? For instance, could current campaigns or coalitions be marshalled to address inclusion in climate decision-making?

\section{Coordination Are there appropriate coordination} structures and bodies in place to align policies, plans, targets, etc., across sectors and to subnational scales? Are all relevant sectors represented and are staff of sufficient seniority to carry out decisions?

\section{GUIDANCE}

Identify where advocates can focus efforts to make decision-making more transparent. In some countries there may be legal requirements that are not being followed. Users may consider data and information that informed policy decisions; which policy instruments will be used to reach policy goals; if there are executive, legislative, or regulatory actions that must be taken before implementation can occur, are these clear and agreed upon; what implementation indicators will be used and how will the results be disclosed; the timeline for implementation; how stakeholder input was taken into account; and monitoring and evaluation procedures.

Legal requirements alone don't guarantee that participation is inclusive or protect against elite capture, but strong rules can help ensure decision-making is not shut off from the public. Consider also whether there are specific rights for indigenous groups and whether there is disparity in implementation.

\section{OUTPUT}

Brief description, to devote time, even if there are newfound political incentives to be more inclusive.

These norms may persist even if rules promote gender or social equality. Consider what drives these norms and what factors may influence their change. Are there leaders who may be leveraged to influence the uptake of inclusive, equitable decision-making processes?

Gathering a full picture of how different factors contribute to coordination issues may entail significant work, so users should assess whether this analysis has been conducted and if it is central to addressing the identified challenge. Factors may include unclear or unfunded responsibilities, poor information sharing, and lack of oversight, among others.
Clarity on where decision-making is not conforming to rules, norms, or good practices and where capacity building or advocacy could focus. based on experience of key stakeholders and supported by evidence, where possible, of alignment between rules and practice on public participation.

Experiences of different stakeholders in influencing climate policy processes

SOURCES

Interviews, past experience

Legal review and interviews

Insight as

to whether

Interviews, review

longstanding

norms may be

shifting and

whether these

changes can be

leveraged

Clearer

Policy and

understanding of

why coordination

planning

problems persist of academic or

white papers government websites, interview corroboration 


\section{CATEGORY ASSESSMENT QUESTION}

Coordination Who chairs the body and to whom is this authority accountable?

\section{GUIDANCE}

This may be readily available in public documentation or it may require asking authorities.

\section{Coordination Do the decisions of the coordinating} body carry the authority-either through legal mandate or high-level political support-to compel action? If not, through what means of influence do these bodies try to achieve results?

\section{Coordination Are non-state actors/civil society included on coordination bodies? If so, how are they selected/elected and how are they able to influence decision- making?}

Strengthening the mandate, budget, or structural authority of the body may enhance implementation of its recommendations/directives. Also consider how its authority has shifted during different political regimes if it has been around long enough.

In some cases, NGOs, academia, indigenous groups, and others are represented on climate governance councils, while industry may be as well. It may be worthwhile to examine how effectively these councils mediate power dynamics.

$\begin{array}{ll}\text { Coordination } & \begin{array}{l}\text { Is there competition for budgetary } \\ \text { resources, political influence, or } \\ \text { administrative authority among different } \\ \text { ministerial actors that could impact } \\ \text { coordination and cooperation? }\end{array} \\ \begin{array}{ll}\text { Policy } \\ \text { coherence }\end{array} & \begin{array}{l}\text { To what extent are policies across } \\ \text { sectors consistent with national climate } \\ \text { goals and aligned with development } \\ \text { plans? }\end{array}\end{array}$

\begin{tabular}{|c|c|}
\hline $\begin{array}{l}\text { Policy } \\
\text { coherence }\end{array}$ & $\begin{array}{l}\text { To what extent do the plans and } \\
\text { programs of key sectors reflect } \\
\text { implementation of climate risks and } \\
\text { targets in policies? Are there sufficient } \\
\text { incentives (mandates, performance } \\
\text { goals, budget, oversight) to enable this? }\end{array}$ \\
\hline
\end{tabular}

This requirement may be embedded in administrative law, framework climate laws, agency rules, or elsewhere. If it's not occurring, there may be a discrepancy between law and practice.

While this information may be hard to come by or verify, users can look at past issues or talk with former staff.

Users should undertake this analysis only if it has not already been conducted and if it is critical to understanding the scope of the problem.

See, for instance, the work under the Action on Climate Today on mainstreaming of climate adaptation in South Asia by Oxford Policy Management.

\section{OUTPUT}

Determination of whether oversight is being exercised or if there are multiple lines of accountability

Response to this question may help explain challenges

to policy

coherence

Assessment of whether decisionmaking could be improved through better representation of stakeholders or civil society

Transparency and accountability of coordination bodies

\section{SOURCES}

Interviews, reports

Legal review, interviews

Law, policy, or guideline that established body; interviews

$\begin{array}{ll}\begin{array}{l}\text { Underlying } \\ \text { dynamics that may } \\ \text { affect coordination }\end{array} & \begin{array}{l}\text { Off-the-record } \\ \text { interviews; } \\ \text { discussions with } \\ \text { stakeholders and } \\ \text { other insiders }\end{array} \\ \begin{array}{ll}\text { Evidence of } \\ \text { progress in } \\ \text { implementing } \\ \text { national goals } \\ \text { across sectors }\end{array} & \text { interviews } \\ \begin{array}{l}\text { Policy alignment } \\ \text { may not result }\end{array} & \begin{array}{l}\text { Budgets, } \\ \text { in changes }\end{array} \\ \begin{array}{l}\text { in programs, reviews, } \\ \text { investments, and }\end{array} & \\ \text { practices } & \end{array}$


Table C1 | Questions on Stakeholders and Interests

Stakeholders and interests: This section helps users consider how different stakeholders might react to new climate policies, regulations, or governance structures based on their interests, constituents, or prevailing ideologies. If a stakeholder mapping has been conducted already, these questions may supplement that work.

\begin{tabular}{l|l}
\hline CATEGORY & ASSESSMENT QUESTION \\
\hline Co-benefits & $\begin{array}{l}\text { If the challenge is focused on policy } \\
\text { implementation, what co-benefits have } \\
\text { been identified? Are these co-benefits } \\
\text { recognized by decision-makers and } \\
\text { stakeholder groups? If not, is there } \\
\text { a lack of agreement, awareness, or } \\
\text { ideological opposition? }\end{array}$ \\
$\begin{array}{l}\text { Power } \\
\text { relations }\end{array}$ & $\begin{array}{l}\text { To what extent does the executive } \\
\text { branch share power across branches } \\
\text { of government and with subnational } \\
\text { authorities? }\end{array}$
\end{tabular}

State-society To what extent is clientelism prevalent relations in policy decisions, investments, and service delivery? To what extent could patronage affect implementation of climate policies?

Decision- Who are the decision-makers that need makers to be influenced and what actions do they need to take?

Constituencies Who are they influenced by? For instance, their constituencies, their shareholders, their donors?

Power holders Are there stakeholders with influence and power but who prefer to remain behind the scenes?

Distributional
impacts

\section{GUIDANCE} affected and interested stakeholders; consider employment, improved quality of services, reduced climate impact exposure, enhanced social security net, or otherwise.
This helps for understanding the scope of

\section{OUTPUT}

Mapping of co-benefits of climate policy to potentially interested stakeholder groups
SOURCES

Review of public statements, media, national development strategies

Consider: relative powers in lawmaking and budgetary oversight between the legislature and executive; whether the judiciary has constitutional or actual power to challenge the executive; to what extent can subnational authorities exercise power and whether this is contingent on political party affiliation.

This may be relevant in assessing policy equity, implementation of just transition frameworks, accountability of climate finance, or climate policy decisions where benefits are traded for political support.

There may be multiple sets of decision-makers and decisions that interlock around a key goal; e.g., better collective action of non-state actors to influence climate policy as well as greater commitment from key agencies to gathering feedback.

It may be worth spending time to assess whether the influence of various groups is in flux-for instance, is an industry waning or is a politician weighing their legacy?

In contexts with a high degree of informality, there may be nominal decision-makers and less visible powerholders.

"Positively benefit" often means material benefits (carbon price revenue, improved air quality, resilience, etc.) but may also mean improved procedural fairness, reputational

benefits, or otherwise.

\section{Summary of how power} is shared in rulemaking, revenue generation and sharing, and oversight and accountability that may affect how climate policies are created, implemented, and enforced

Identification of risks for policy implementation

Mapping of decisionmakers, their respective roles, and whether these are being fulfilled

Analysis of what and who motivates key decisionmakers

Interviews, past positions, affiliations

May inform influence strategy if nominal decision-makers hold less power

Identify policy beneficiaries who may become policy constituencies
Political science literature, empirical experience

Interviews, informal discussions

Group discussions, interviews
Interviews

Policy analysis, interviews likely to be positively affected if the policy change you are seeking occurs? 


\section{\begin{tabular}{l|l} 
CATEGORY & ASSESSMENT QUESTION
\end{tabular}}

Distributional Are these groups organized in support impacts of the policy? If not, why not? Is there an information or understanding gap on the issue?

\section{Distributional Which stakeholders or groups are most impacts likely to be negatively affected if there is a change in policy or enforcement? \\ Stakeholder Are they organized to oppose policy mapping change? In which policy venue are they most likely to exert pressure?}

$\begin{array}{ll}\text { Stakeholder } & \text { Do they enjoy clout or influence on any } \\ \text { mapping } & \text { of the above decision-makers? If so, } \\ & \text { how? }\end{array}$

Stakeholder mapping

\section{Stakeholder mapping}

Civic space

\section{External incentive shifts} so, do they not see it as affecting thei interests?
Has the previous outcome influenced the current alignment of stakeholders?

Are there ways in which climate actions are constrained that affect incentives, for instance, through restrictions on protests, criminalization of civil society, or other constraints on collective action? Is there evidence that international diplomacy, new markets, technological innovations, international finance, or other external factors are providing new incentives for powerholders to shift their positions?

\section{GUIDANCE}

Some groups may not see climate as "their issue" and may be limited in resources to join the policy process. However, issue bundling, or a better understanding of the policy outputs, may broaden the scope of stakeholders. For this and the next question, review whether a distributional impacts analysis has been conducted.

Consider both industries and workers, as well as other associated interest groups

Assess how well these groups are likely to be organized in opposition based on past policy conflicts or organized lobbying.

Consider campaign contributions, employment generated in key geographies, direct voter influence.

\section{OUTPUT}

Should inform campaign strategy if the challenge involves building a larger coalition to support climate action

\section{SOURCES}

Interviews, prior experience

\section{Consider how policy costs may be buffered or compensated, if necessary \\ Mapping of likely opposition and how capable they are of defeating policy enactment or implementation}

\section{Mechanisms of influence in} stakeholder mapping
Desk research, interviews

Interviews

Previous policy positions, public statements, interviews

Stakeholder mappingDesk research, Coalitions may be broadened if groups that have not traditionally been active understand that the interests and influence interviews issue affects their material interests, values, or well-being.

It can be helpful to examine how past contested policies played out politically and whether stakeholders and decision-makers' positions have shifted.

Enabling environment

It may be difficult to gather evidence to ascertain this, so users should consider whether this is possible based on these developments and what is known about past positions.
Understanding of coalition dynamics and how previous experience shapes current positions

Fear of reprisals or a legacy of crackdowns on activists may dampen collective action.

Potential windows of opportunity or shifts in Desk research, interviews
Literature review, interviews

Desk research, interviews with NGOs and activists 


\section{CATEGORY $\quad$ ASSESSMENT QUESTION}

System shocks Has the impact of the COVID-19 pandemic prompted new policymaking discussions or recovery efforts that link to reduced climate risk, clean energy economies, or other policy ideas that can be promoted to enhance equitable recovery?

$\begin{array}{ll}\text { Policy venues } & \begin{array}{l}\text { What kind of policymaking process, } \\ \text { forum, or other platform has been used } \\ \text { for collective action and to what extent } \\ \text { has it proved effective? }\end{array} \\ \text { Government } & \begin{array}{l}\text { Is there a recent or upcoming shift } \\ \text { reorganization }\end{array} \\ & \begin{array}{l}\text { in principal-agent dynamics due to } \\ \text { a new administration, restructuring, } \\ \text { opportunity? }\end{array} \\ \text { Policy venues } & \begin{array}{l}\text { Are there policy venues through } \\ \text { which stakeholder groups may access } \\ \text { decision-makers that are not being } \\ \text { utilized? What are the barriers to } \\ \text { access? }\end{array}\end{array}$

$\begin{array}{ll}\begin{array}{l}\text { Grievance } \\ \text { mechanisms }\end{array} & \begin{array}{l}\text { Is there scope for legal challenges, } \\ \text { if necessary? If so, under which } \\ \text { provisions? }\end{array}\end{array}$

Source: Authors

\section{GUIDANCE}

There are risks as well as opportunities-for instance, through rollbacks of safeguards to protect from social and environmental harm or further entrenchment of carbon-intensive economic interests.

This may include a civil society network that is actively engaged on the issue as well as a forum or space for interaction with decisionmakers.

This may be assessed through direct conversations with new officials, shifts in agency rules and practices, or anticipated based on political platforms.

\section{Stakeholders, particularly those with less} access to power, may be locked out of or unaware of policy venues where most decisionmaking takes place.

If laws are not being upheld and other avenues have been exhausted, this may be a viable option, depending on costs, likelihood of legal standing, civil society, and judiciary capacity.

\section{OUTPUT}

Brief summary of policy proposals and windows of opportunity to strengthen political commitment or climate governance

Consideration of whether existing platforms are

Desk research, sufficient interviews

Identif

Identification of

policymaking processes

that may be more

inclusive, transparent, or accountable

\section{Consider whether focusing Interviews} resources on changing composition and practices on existing policy venues or shifting to new ones is more strategic

Relevant provisions (if this question is deemed important and necessary)

\section{SOURCES}

Review of policies, public statements, interviews Desk research

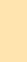
Legal research 
Table D1 | Questions on Ideas and Narratives

Ideas and Narratives: Ideas and narrative shape what policymakers and stakeholders see as the problem and the set of solutions. In some cases this can limit the effectiveness or equity of climate action.

\begin{tabular}{|c|c|c|c|c|}
\hline CATEGORY & DIAGNOSTIC QUESTION & GUIDANCE & OUTPUT & SOURCES \\
\hline $\begin{array}{l}\text { Ideas and } \\
\text { ideology }\end{array}$ & $\begin{array}{l}\text { What is the prevailing idea on how this } \\
\text { issue should be addressed? Is this idea } \\
\text { linked to any particular ideology and } \\
\text { does it have scientific backing? Who are } \\
\text { its main proponents? }\end{array}$ & $\begin{array}{l}\text { Dominant ideas can determine what } \\
\text { policymakers and the public see as } \\
\text { possible. In some cases, where policy } \\
\text { change has stalled, new ideas can capture } \\
\text { the support of new actors-for example, the } \\
\text { relative prominence of cap and trade and } \\
\text { carbon taxes as viable policy ideas over } \\
\text { time. }\end{array}$ & $\begin{array}{l}\text { Clearer sense of which } \\
\text { ideas for climate solutions } \\
\text { have gained prominence } \\
\text { and how that might affect } \\
\text { stakeholder dynamics and } \\
\text { broader public support }\end{array}$ & $\begin{array}{l}\text { Desk research, } \\
\text { discussion, } \\
\text { interviews }\end{array}$ \\
\hline $\begin{array}{l}\text { Ideas and } \\
\text { ideology }\end{array}$ & $\begin{array}{l}\text { Is there a competing idea? If so, who is } \\
\text { proposing it and why? }\end{array}$ & $\begin{array}{l}\text { Competing ideas may be spurred by } \\
\text { technological innovation, new information } \\
\text { (such as risks or effectiveness of other } \\
\text { ideas), or ideological underpinnings } \\
\text { (markets versus regulation). }\end{array}$ & $\begin{array}{l}\text { Dynamics of competing } \\
\text { ideas and how they might } \\
\text { appeal to political actors } \\
\text { and their constituencies }\end{array}$ & $\begin{array}{l}\text { Policy briefs, } \\
\text { campaign } \\
\text { literature, press } \\
\text { events }\end{array}$ \\
\hline $\begin{array}{l}\text { Dominant } \\
\text { narrative }\end{array}$ & $\begin{array}{l}\text { What is dominant narrative regarding } \\
\text { the challenge (i.e., is it regarded as } \\
\text { a challenge and what solutions are } \\
\text { considered)? How long has it been in } \\
\text { place and does it need to change for } \\
\text { there to be action? }\end{array}$ & $\begin{array}{l}\text { This question may be addressed } \\
\text { through workshop discussions with key } \\
\text { participants. }\end{array}$ & $\begin{array}{l}\text { Brief summary as it } \\
\text { pertains to the identified } \\
\text { challenge based on expert } \\
\text { input, experience, or } \\
\text { literature }\end{array}$ & $\begin{array}{l}\text { Desk research, } \\
\text { discussion, } \\
\text { interviews }\end{array}$ \\
\hline Equity & $\begin{array}{l}\text { To what extent do discussions of climate } \\
\text { solutions and policy proposals consider } \\
\text { the equity implications across different } \\
\text { social groups? Are there processes } \\
\text { for representation and safeguards } \\
\text { to ensure climate actions do not } \\
\text { exacerbate inequalities and to prioritize } \\
\text { equity gains? }\end{array}$ & $\begin{array}{l}\text { Consider how data on equity impacts } \\
\text { informs policy discussions, the engagement } \\
\text { of groups focused on equity, and the degree } \\
\text { to which equity is prioritized as a policy } \\
\text { goal. }\end{array}$ & $\begin{array}{l}\text { Quick equity risk } \\
\text { assessment of current } \\
\text { climate policy discussions }\end{array}$ & $\begin{array}{l}\text { Review of } \\
\text { climate equity } \\
\text { frameworks, } \\
\text { policy analysis }\end{array}$ \\
\hline $\begin{array}{l}\text { Narrative and } \\
\text { communications }\end{array}$ & $\begin{array}{l}\text { How are media engaging on this issue? } \\
\text { Does framing capture the problem and } \\
\text { solutions accurately? }\end{array}$ & $\begin{array}{l}\text { While an exhaustive analysis of media } \\
\text { coverage likely isn't in the scope for most } \\
\text { users, workshop discussions and a review } \\
\text { of major coverage in the past two to three } \\
\text { years may be helpful. }\end{array}$ & $\begin{array}{l}\text { Understanding of what } \\
\text { has/hasn't driven media } \\
\text { engagement and an } \\
\text { identification of whom to } \\
\text { engage along with relevant } \\
\text { analysis and narratives }\end{array}$ & $\begin{array}{l}\text { Review of } \\
\text { coverage }\end{array}$ \\
\hline Communications & $\begin{array}{l}\text { Who are the messengers that may have } \\
\text { legitimacy among targets of influence? }\end{array}$ & $\begin{array}{l}\text { This can be discussed in workshops and } \\
\text { corroborated through interviews. }\end{array}$ & $\begin{array}{l}\text { Comparison of whether } \\
\text { coverage and discussion } \\
\text { of the challenge or } \\
\text { solutions has included } \\
\text { those organizations or } \\
\text { outlets that may be more } \\
\text { influential }\end{array}$ & $\begin{array}{l}\text { Interviews, } \\
\text { workshop } \\
\text { discussions }\end{array}$ \\
\hline
\end{tabular}


1. Examples include the NDC Toolbox (https://ndcpartnership. org/ndc-toolbox) and the NewClimate Policy Database (http:// climatepolicydatabase.org/index.php?title=About_the database).).http://climatepolicydatabase.org/index.php?title=About_ the_database).

2. Such as the United Nations Development Programme's Gender Equality in National Climate Action: Planning for Gender-Responsive Nationally Determined Contributions (http://ndcpartnership.org/toolbox/ gender-equality-national-climate-action-planning-gender-responsivenationally-determined).

3. See for instance, Averchenkova 2019.

4. Of the 104 countries that have stated their intention to enhance ambition as of mid-2020, the vast majority are from Africa or are Small Island Developing States from the Caribbean and South Pacific. To track countries' NDCs, visit https://www.climatewatchdata.org/2020-ndctracker.

5. According to its website, the Climate Action Tracker "covers all the biggest emitters and a representative sample of smaller emitters covering about $80 \%$ of global emissions and approximately $70 \%$ of global population." See more information about the Climate Action Tracker at https://climateactiontracker.org/about/.

6. Rosenau (1990) and Chhotray and Stoker (2009) as cited in the IPCC's report (Edenhofer et al. 2014).

7. The United States has failed to enact national climate legislation, though subnational governments have had success. Australia's carbon tax was repealed three years after passage. And while the UK has met its carbon targets thus far, it is not on track to meet future emissions targets without further action, according to the UK's Climate Change Committee. (Read the Committee on Climate Change's report at https://www.theccc. org.uk/publication/reducing-uk-emissions-2020-progress-report-toparliament/).

8. See country ratings at https://climateactiontracker.org/.

9. For more information on World Bank classifications of countries, see https://datahelpdesk.worldbank.org/knowledgebase/articles/906519world-bank-country-and-lending-groups.

10. This estimate reflects pre-tax subsidies. By including externalities of fossil fuel consumption, the IMF estimates \$5.2 trillion in 2017.

11. For more information on informal and customary political systems, see the University of Birmingham's GSDRC page at https://gsdrc.org/topicguides/political-systems/informal-and-customary-political-systems/.

12. For example, the "We Are Still In" declaration of US subnational governments and non-state actors and organizations that joined to support climate action to meet the goals of the Paris Agreement following the Trump administration's decision to withdraw the United States from the deal in 2017. Read the "We Are Still In" declaration at https://www.wearestillin.com/we-are-still-declaration.
13. Including financial support, capacity-building, and technology transfer.

14. Examples of international agreements that do impose such obligations include the Aarhus Convention and the Escazú Agreement.

15. For example, by lowering the carbon price or lobbying for a longer timeline to reach an emissions or renewable energy target.

16. PEA and TWP are not the only methods to have emerged that fundamentally question change processes that rely on technical knowledge as well as model approaches. Others include Problem Driven Iterative Adaptation (PDIA) and Doing Development Differently (DDD) (Andrews et al. 2012; Overseas Development Institute 2016).

17. For practitioner experience on applying PEA, see, for example, Menocal et. al (2018) for USAID and Whaites (2017) for the UK government.

18. For some users, increasing engagement with journalists may be a priority, but this consideration should be balanced with maintaining the confidentiality of closed-door discussions.

19. For a more comprehensive elaboration of how to organize these discussions, based on experience conducting climate governance assessments for the purpose of mainstreaming adaptation in development policy under Action on Climate Today, see Gogoi and Bisht (2018).

20. This timeline is for the $1.5^{\circ} \mathrm{C}$ target. In $2^{\circ} \mathrm{C}$ scenarios, $\mathrm{CO}_{2}$ must reach net-zero on average between 2070-85 for a 50-66 percent likelihood of reaching the target (Levin and Davis 2019).

21. While there is no one agreed-upon definition for a just transition, International Labour Organization (2015) states: "Decent work, poverty eradication and environmental sustainability are three of the defining challenges of the twenty-first century. Economies must be productive to meet the needs of the world's growing population. Societies must be inclusive, providing opportunities for decent work for all, reducing inequalities and effectively eliminating poverty."

22. The Grantham Research Institute on Climate Change and the Environment at the London School of Economics and the Sabin Center for Climate Change Law at the Columbia Law School provide an updated, searchable database of climate laws, policies, and litigation globally. See the database at https://climate-laws.org/. Climate Watch (www. climatewatchdata.org), managed by World Resources Institute, allows users to search, track, and compare any country's nationally determined contribution (NDC). 
REFERENCES

Adaptation Fund. 2020. Taking Adaptation to the Ground: A Small Grants Facility for Enabling Local-Level Responses to Climate Change. https://www. adaptation-fund.org/project/taking-adaptation-to-the-ground-a-smallgrants-facility-for-enabling-local-level-responses-to-climate-change/. Accessed February 16.

Allen, Myles R., Opha Pauline Dube, William Solecki, Fernando AragónDurand, Wolfgang Cramer, Stephen Humphreys, Mikiko Kainuma, et al. 2018. "Framing and Context." In Global Warming of $1.5^{\circ} \mathrm{C}$. Geneva: IPCC.

Andrews, Matt, Lant Pritchett, and Michael Woolcock. 2012. "Escaping Capability Traps through Problem-Driven Iterative Adaptation (PDIA)." Working Paper 299. Washington, DC: Center for Global Development.

Arent, Douglas, Channing Arndt, Mackay Miller, Finn Tarp, and Owen Zinaman, eds. 2017. The Political Economy of Clean Energy Transitions. Oxford and New York: Oxford University Press.

Atlantic Fellows for Social and Economic Equity. 2019. Multidimensional Inequality Framework. London, UK: International Inequalities Institute at the London School of Economics and Political Science.

Averchenkova, Alina. 2019. "Legislating for a Low-Carbon and ClimateResilient Transition: Learning from International Experiences." Elcano Policy Paper. Madrid: Real Instituto Elcano.

Averchenkova, Alina, and Samuela Bassi. 2016. "Beyond the Targets: Assessing the Political Credibility of Pledges for the Paris Agreement." Policy Brief. London: Grantham Research Institute on Climate Change and the Environment and Centre for Climate Change Economics and Policy, London School of Economics and Political Science.

Barua, Priya, Taryn Fransen, and David Wood. 2014. Climate Policy Implementation Tracking Framework. Washington, DC: World Resources Institute.

Bernstein, Steven, and Matthew Hoffman. 2018. "The Politics of Decarbonization and the Catalytic Impact of Subnational Climate Experiments." Policy Sciences 51: 189-211.

Bruch, Carl, Scott Schang, John Pendergrass, Scott Fulton, Nora MoragaLewy, Merideth Wright, and Greta Swanson. 2019. Environmental Rule of Law: First Global Report. Nairobi: United Nations Environment Programme.

C40 Cities. 2020. "City Action to Address the Climate Emergency." https:// www.c40.org/other/city-commitments. Accessed February 16.

Chhotray, Vasudha, and Gerry Stoker. 2009. "Governance and International Relations." In Governance Theory and Practice, edited by Vasudha Chhotray and Gerry Stoker, 76-96. London, UK: Palgrave Macmillan.

Climate Watch. 2020، "2020 NDC Tracker." https://www.climatewatchdata. org/2020-ndc-tracker. Washington, DC: World Resources Institute.

Coady, David, lan Parry, Nghia-Piotr Le, and Baoping Shang. 2019. "Global Fossil Fuel Subsidies Remain Large: An Update Based on Country-Level Estimates." Working Paper. Washington, DC: International Monetary Fund.
Corduneanu-Huci, Cristina, Alexander Hamilton, and Issel Masses Ferrer. 2013. Understanding Policy Change: How to Apply Political Economy Concepts in Practice. Washington, DC: World Bank.

Dagnet, Yamide, Nathan Cogswell, Neil Bird, Mathilde Bouyé, and Marcelo Rocha. 2019. Building Capacity for Paris Agreement's Enhanced Transparency Framework: What Can We Learn from Countries' Experiences and UNFCCC Processes? Washington, DC: World Resources Institute.

DeFries, R., O. Edenhofer, A. Halliday, G. Heal, T. Lenton, M. Puma, J. Rising, et al. 2019. The Missing Economic Risks in Assessments of Climate Change Impacts, London: Grantham Research Institute on Climate Change and the Environment.

Department for International Development (DFID). 2004 Drivers of Change. London: DFID. http://www.gsdrc.org/docs/open/doc59.pdf.

Edenhofer, O., R. Pichs-Madruga, Y. Sokona, E. Farahani, S. Kadner, K. Seyboth, A. Adler, et al. 2014. IPCC, 2014: Climate Change 2014: Mitigation of Climate Change. Contribution of Working Group III to the Fifth Assessment Report of the Intergovernmental Panel on Climate Change. Cambridge, UK and New York: Cambridge University Press.

Elliot, Cynthia, Kelly Levin, Joe Thwaites, Kathleen Mogelgaard, and Yamide Dagnet. 2017. Designing the Enhanced Transparency Framework Part 1: Reporting under the Paris Agreement. Washington, DC: World Resources Institute.

Farand, Chloé. 2020. "Citizens' Assemblies on Climate Change Seek to Shape Post-Covid Recovery." Climate Home News, April 17.

Fay, Marianne, Stephane Hallegatte, Adrien Vogt-Schilb, Julie Rozenberg, Ulf Narloch, and Tom Kerr. 2015. Decarbonizing Development: Three Steps to a Zero-Carbon Future. Washington, DC: World Bank.

Fisher, Jonathan, and Heather Marquette. 2014. "Donors Doing Political Economy Analysis: From Process to Product (and Back Again?)" Research Paper. Birmingham, UK: Development Leadership Program, University of Birmingham.

Frankhauser, Sam, Alina Averchenkova, and Jared J. Finnegan. 2018. "10 Years of the UK Climate Change Act." Policy Brief. London: Center for Climate Change Economics and Policy and Grantham Research Institute on Climate Change and the Environment.

Fritz, Verena, Brian Levy, and Rachel Ort. 2014. Problem-Driven Political Economy Analysis. Washington, DC: World Bank.

Global Commission on Adaptation. 2019. Adapt Now: A Global Call for Leadership on Climate Resilience. Global Commission on Adaptation.

Global Commission on the Economy and Climate. 2018. Unlocking the Inclusive Growth Story of the 21st Century: Accelerating Climate Action in Urgent Times. Washington, DC: World Resources Institute.

Gogoi, Elizabeth, and Harshita Bisht. 2018. Climate Governance Assessment: How to Note. Oxford Policy Management. 
Government of India. 2008. National Action Plan on Climate Change. New Delhi: Ministry of Environment, Forest and Climate Change. http://www.nicra-icar.in/nicrarevised/images/Mission\%20Documents/ National-Action-Plan-on-Climate-Change.pdf.

Hale, Thomas. 2018. "The Role of Sub-state and Non-state Actors in International Climate Processes." Research Paper. November 28. Chatham House.

Harrison, Tom, and Genia Kostka. 2013، "Balancing Priorities, Aligning Interests: Developing Mitigation Capacity in China and India." Comparative Political Studies (November 19): 450-480.

Hout, Wil. 2015. Putting Political Economy to Use in Aid Policies. OECD.

Hudson, David, Claire Mcloughlin, Chris Roche, and Heather Marquette. 2018. Inside the Black Box of Political Will: 10 Years of Experience from the Development Leadership Program. Development Leadership Program.

International Labour Organization. 2015. Guidelines for a Just Transition towards Environmentally Sustainable Economies and Societies for All. Geneva: International Labour Organization.

Inchauste, Gabriela, David G. Victor, and Eva Schiffer. 2018. Good Practice Note 9: Assessing the Political Economy of Energy Subsidies to Support Policy Reform Operations. Washington, DC: World Bank.

Independent Evaluation Group. 2016. "The Role of Political Economy Analysis in Development Policy Operations." Working Paper. Washington, DC: World Bank Group.

Jagers, Sverker C., and Johannes Stripple. 2003. "Climate Governance Beyond the State." Global Governance 9 (3): 385-99.

Johnson, Oliver W., Jenny Yi-Chen Han, Anne-Louise Knight, Sofie Mortensen, May Thazin Aung, Michael Boyland, and Bernadette P. Resurrección. 2020. Assessing the Gender and Social Equity Dimensions of Energy Transitions. Stockholm: Stockholm Environmental Institute.

Jordan, Andrew, Dave Huitema, Jonas Schoenefeld, Harro van Asselt, and Johanna Forster. 2018. "Governing Climate Change Polycentrically: Setting the Stage." In Governing Climate Change: Polycentricity in Action? edited by Andrew Jordan, Dave Huitema, Harro van Asselt, and Johanna Forster, 3-26. Cambridge, UK: Cambridge University Press.

Laws, Ed, and Heather Marquette. 2018. "Thinking and Working Politically: Reviewing the Evidence on the Integration of Politics into Development Practice over the Past Decade." Working and Discussion Paper. London: Overseas Development Institute.

Lazarus, Richard J. 2010. "Super Wicked Problems and Climate Change: Restraining the Present to Liberate the Future." Environmental Law Reporter, 40.

Lee, Alan David, and Zainab Usman. 2018. Taking Stock of the Political Economy of Power Sector Reforms in Developing Countries: A Literature Review. Washington, DC: World Bank Group.
Levin, Kelly, and Chantal Davis. 2019. "What Does 'Net-Zero Emissions' Mean? Six Common Questions Answered." Blog. September 17. World Resources Institute. https://www.wri.org/blog/2019/09/what-does-net-zero-emissionsmean-6-common-questions-answered.

Levin, Kelly, Benjamin Cashore, Steven Bernstein, and Graeme Auld. 2012. "Overcoming the Tragedy of Super Wicked Problems: Constraining Our Future Selves to Ameliorate Global Climate Change." Policy Science 45 (May): 123-52.

Levy, Brian. 2014. Working with the Grain: Integrating Governance and Growth in Development Strategies. New York: Oxford University Press.

Lockwood, Matthew. 2016. "The Political Dynamics of Green Transformations: Feedback Effects and Institutional Context." In The Politics of Green Transformations, edited by lan Scoones, Melissa Leach, and Peter Newell, 86-101. London: Routledge.

McCulloch, Neil, and Laure-Hélène Piron. 2019. "Thinking and Working Politically: Learning from Practice." Overview to Special Issue. Development Policy Review, 37 (S1): 01-015.

Menocal, Alina Rocha, Marc Cassidy, Sarah Swift, David Jacobstein, Corinne Rothblum, and Ilona Tservil. 2018. Thinking and Working Politically through Applied Political Economy Analysis: A Guide for Practitioners. Washington, DC: USAID.

Mildenberger, Matto. 2020. Carbon Captured: How Business and Labor Control Climate Politics. Cambridge, MA: MIT Press.

Moncrieffe, Joy, and Cecilia Luttrell. 2005. An Analytical Framework for Understanding the Political Economy of Sectors and Policy Arenas. London: Overseas Development Institute.

Morrison, Tiffany H., W. Neil Adger, Katrina Brown, Maria Carmen Lemos, Dave Huitema, and Terry P. Hughes. 2017. "Mitigation and Adaptation in Polycentric Systems: Sources of Power in the Pursuit of Collective Goals." WIREs Climate Change 8 (5) e479.

NewClimate Institute and Climate Analytics. 2019a. Climate Action Tracker: Warming Projections Global Update, December 2019. Berlin, Germany: NewClimate Institute; Climate Analytics.

NewClimate Institute and Climate Analytics. 2019b. Climate Governance: Assessing Governments' Ability and Readiness to Transform Their Countries into Zero Emissions Societies. Climate Action Tracker.

NewClimate Institute and Climate Analytics. 2020. "The Climate Action Tracker." https://climateactiontracker.org/. Accessed August 17.

North, Douglass C. 1990. Institutions, Institutional Change, and Performance. New York: Cambridge University Press.

Overseas Development Institute. 2016. Doing Development Differently: Who We Are, What We're Doing, What We're Learning. London, UK: Overseas Development Institute.

Piron, Laure-Hélène, Aislin Baker, Laura Savage, and Katie Wiseman. 2016. Is DFID Getting Real about Politics? Brighton, UK: Policy Practice. 
Rabe, Barry G. 2018. Can We Price Carbon? Cambridge, MA; London: MIT Press.

Repetto, Robert, ed. 2006. Punctuated Equilibrium and the Dynamics of US Environmental Policy. New Haven, CT: Yale University Press.

Rodrik, Dani. 2014. "When Ideas Trump Interests: Preferences, Worldviews, and Policy Innovations." Journal of Economic Perspectives 189-208.

Rosenau, James N. 1990. Turbulence in World Politics: A Theory of Change and Continuity. Princeton University Press.

Roy, J., P. Tschakert, H. Waisman, S. Abdul Halim, P. Antwi-Agyei, P. Dasgupta, B. Hayward, et al. 2018. "Sustainable Development, Poverty Eradication, and Reducing Inequalities." In Global Warming of $1.5^{\circ} \mathrm{C}$ : An IPCC Special Report on the Impacts of Global Warming of $1.5^{\circ} \mathrm{C}$ above Pre-industrial Levels and Related Global Greenhouse Gas Emission Pathways, in the Context of Strengthening the Global Response to the Threat of Climate Change, Sustainable Development, and Efforts to Eradicate Poverty, edited by V. Masson-Delmotte, P. Zhai, H.O. Pörtner, D. Roberts, J. Skea, P.R. Shukla, A. Pirani, et al., 445-538. Geneva: IPCC.

Schmitz, Hubert. 2016. "Who Drives Climate-Relevant Policies in the Rising Powers?" New Political Economy 22 (5): 521-40.

Shakya, Clare, Katherine Cooke, Naman Gupta, Zac Bull, and Sam Greene. 2018. Building Institutional Capacity for Enhancing Resilience to Climate Change: An Operational Framework and Insights from Practice. London: Oxford Policy Management; IIED.

Sovacool, Benjamin K., and Björn-Ola Linnér. 2016. The Political Economy of Climate Change Adaptation. London: Palgrave Macmillan.

Sovacool, Benjamin K., and Joseph Scarpaci. 2016. "Energy Justice and the Contested Petroleum Projects of Stranded Assets: Policy Insights from the Yasuní-ITT Initiative in Ecuador." Energy Policy 95 (August): 158-71.

Taibi, Fatima-Zahra, and Susanne Konrad. 2016. Pocket Guide to NDCs under the UNFCCC. European Capacity Building Initiative.
Tanner, Thomas, and Jeremy Allouche. 2011. "Towards a New Political Economy of Climate Change and Development." IDS Bulletin 42 (3).

United Nations Environment Programme. 2019. Emissions Gap Report 2019. Nairobi: UNEP.

Unsworth, Sue. 2007. Framework for Strategic Governance and Corruption Analysis: Designing Strategic Responses towards Good Governance. Clingendael, Netherlands: Clingendael Institute.

Van Asselt, Harro, and Fariborz Zelli. 2018. "International Governance: Polycentric Governing by and beyond the UNFCCC." In Governing Climate Change: Polycentricity in Action? edited by Andrew Jordan, Dave Huitema, Harro van Asselt, and Johanna Forster, 29-46. Cambridge University Press.

Victor, David. 2009. Untold Billions: Fossil Fuel Subsidies, Their Impacts and the Path to Reform. Geneva: Global Subsidies Initiative; International Institute for Sustainable Development.

Vogt-Schilb, Adrien, and Stephane Hallegatte. 2017. Climate Policies and Nationally Determined Contributions: Reconciling the Needed Ambition with the Political Economy. Washington, DC: Inter-American Development Bank.

Whaites, Alan. 2017. The Beginner's Guide to Political Economy Analysis. United Kingdom: National School of Government International.

Whitley, Shelagh, and Laurie van der Burg. 2018. "Reforming Fossil Fuel Subsidies: The Art of the Possible." In The Politics of Fossil Fuel Subsidies and their Reform, edited by Jakob Skovgaard and Harro Van Asselt, 47-65. Cambridge: Cambridge University Press.

World Bank Group. 2017. Governance and the Law. Washington, DC: World Bank Group.

Worker, Jesse. 2017. National Climate Change Governance: A Topic Guide. Birmingham, UK: GSDRC, University of Birmingham. 


\section{ACKNOWLEDGMENTS}

We are pleased to acknowledge our institutional strategic partners, who provide core funding to WRI: Netherlands Ministry of Foreign Affairs, Royal Danish Ministry of Foreign Affairs, and Swedish International Development Cooperation Agency.

The authors are grateful to the following reviewers: Catherine Anderson, Mathilde Bouye, Kathleen Buckingham, Gabriela Burdiles, Nathan Cogswell, Natalie Elwell, Carole Excell, Joe Foti, Ursula Fuentes, Elizabeth Gogoi, Sohee Gu, Lukas Kahlen, Adna Karamehic-0ates, Ulka Kelkar, Csaba Kiss, Nisha Krishnan, Alan Lee, Carmit Lubanov, Swithin Lui, Patricia Madrigal, Harsha Meenawat, Alina Rocha-Menocal, James Murombedzi, Uttara Narayan, Richard Nash, Carlos Muñoz Piña, Viviane Romeiro, Neelam Singh, Ranping Song, Alan Whaites, and Davida Wood.

Special thanks to Mark Robinson for early guidance and support. Thank you to WRI's Emily Matthews for her generous support in editing and WRI's Emilia Suarez for shepherding the process. We also thank WRI's Romain Warnault for shepherding this paper through production and Ashish Kumar Sen for the copy editing.

We thank the Oak Foundation and the Open Government Partnership Multi-Donor Trust Fund for their support of this work.

\section{ABOUT THE AUTHORS}

Jesse Worker is an associate with the Environmental Democracy Practice in WRI's Governance Center. His work focuses on climate governance, environmental rights, and political economy.

Jesse can be reached at jesse.worker@wri.org.

Niki Palmer is an independent consultant with 20 years of experience in international development with a particular focus on political economy analysis. She is committed to working across sectors and disciplines, striving to bring together views from the humanitarian, climate, and international development fields. Her perspectives have been informed by years of field experience in Africa, Asia, and the Middle East, as well as policy roles at a number of organizations, including the United Nations, the World Bank, and the Department for International Development (DFID).

Niki can be reached at niki.palmer@gmail.com.
World Resources Institute is a global research organization that turns big ideas into action at the nexus of environment, economic opportunity, and human well-being.

\section{Our Challenge}

Natural resources are at the foundation of economic opportunity and human well-being. But today, we are depleting Earth's resources at rates that are not sustainable, endangering economies and people's lives. People depend on clean water, fertile land, healthy forests, and a stable climate. Livable cities and clean energy are essential for a sustainable planet. We must address these urgent, global challenges this decade.

\section{Our Vision}

We envision an equitable and prosperous planet driven by the wise management of natural resources. We aspire to create a world where the actions of government, business, and communities combine to eliminate poverty and sustain the natural environment for all people.

\section{Our Approach}

COUNT IT

We start with data. We conduct independent research and draw on the latest technology to develop new insights and recommendations, Our rigorous analysis identifies risks, unveils opportunities, and informs smart strategies. We focus our efforts on influential and emerging economies where the future of sustainability will be determined.

\section{CHANGE IT}

We use our research to influence government policies, business strategies, and civil society action. We test projects with communities, companies, and government agencies to build a strong evidence base. Then, we work with partners to deliver change on the ground that alleviates poverty and strengthens society. We hold ourselves accountable to ensure our outcomes will be bold and enduring.

SCALE IT

We don't think small. Once tested, we work with partners to adopt and expand our efforts regionally and globally. We engage with decision-makers to carry out our ideas and elevate our impact. We measure success through government and business actions that improve people's lives and sustain a healthy environment.

cc) creative Copyright 2021 World Resources Institute. This work is licensed under the Creative Commons Attribution 4.0 International License.

ccommons $(-)$ To view a copy of the license, visit http://creativecommons.org/licenses/by/4.0/ 